\title{
Deconstructing the Duty to the Tax System: Unfettering Zealous Advocacy on Behalf of Lesbian and Gay Taxpayers
}

\author{
ANTHONY C. INFANTI*
}

\section{TABLE OF CONTENTS}

I. Introduction

II. The Duty to the Tax System: The Heteronormative View ....

A. Justifications for the Duty to the Tax System.

B. Contours of the Duty to the Tax System

1. A Duty that Directly Impacts the Attorney-Client Relationship

2. A Duty that Entails a "Public Responsibility"

III. The Duty to the Tax System: A Lesbian and Gay Perspective......

A. Overt Invidious Discrimination in the Application of the Tax Laws

B. Covert Invidious Discrimination in the Application of the Tax Laws.

1. Contending with the Murkiness

2. Contending with So-Called Guidance .......................... 430

3. Contending with Impossible Burdens ............................ 433

C. Summarizing Our Predicament............................................ 434

IV. Seeing the Duty to the Tax System in a Different Light .............. 436

A. Deconstructing the Duty to the Tax System......................... 436

B. Reconstructing the Duty to the Tax System ........................ 440

V. Concluding Remarks............................................................... 444

\section{Introduction}

When we think about where a lawyer's loyalty lies, our thoughts most naturally turn to her client. ${ }^{1}$ After all, a lawyer owes her client a duty to

*Associate Professor of Law, University of Pittsburgh School of Law. Thanks to Linda Beale for her comments on an earlier draft of this Article and to Bill Lyons for his comments in the course of the editing of this Article. Thanks also to the University of Pittsburgh School of Law for providing financial support for the writing of this article.

${ }^{1}$ See 1 Restatement (Third) of the LaW Governing Lawyers $\$ 16 \mathrm{cmt}$. e (2000) [hereinafter Restatement] ("The responsibilities entailed in promoting the objectives of the client may be broadly classified as duties of loyalty . ..."); Loren D. Prescott, Jr., Challenging the Adversarial Approach to Taxpayer Representation, 30 Loy. L.A. L. Rev. 693, 702 (1997) ("[T]he lawyer's duty of loyalty to the client is an integral and essential part of the adversary system."); 
provide competent representation, ${ }^{2}$ a duty to "act with reasonable diligence and promptness," ${ }^{3}$ a duty to maintain the client's confidences, ${ }^{4}$ and a duty to avoid undertaking a new matter that conflicts with the interests of her client (and, in some cases, even those of a prospective or a former client). ${ }^{5}$ All of these various duties to the client are summed up in the lawyer's charge to act "with commitment and dedication to the interests of the client and with zeal in advocacy upon the client's behalf."

However, a lawyer also sometimes owes a duty to others that trumps her duty to her client. For example, no matter how much it may personally benefit the client, a lawyer is ethically prohibited from counseling her client to engage in criminal or fraudulent conduct; ${ }^{7}$ unlawfully obstructing another party's access to evidence; ${ }^{8}$ unlawfully altering, destroying, or concealing evidence; ${ }^{9}$ falsifying evidence or counseling or assisting a witness to testify falsely $;{ }^{10}$ or making frivolous discovery requests. ${ }^{11}$ Moreover, a lawyer has "special duties ... as [an] officer[] of the court to avoid conduct that undermines the integrity of the adjudicative process." ${ }^{\prime 2}$ Most notably, a lawyer owes a duty of candor to a court, arbitrator, administrative agency, or any "other

David M. Schizer, Enlisting the Tax Bar, 59 TAx L. Rev. 331, 344 (2006) ("In our adversarial system, lawyers generally owe duties to their own client, but not to the other side. In tax planning, the other side is the government, and even when a lawyer is giving advice about planning, she focuses on what would happen if the matter is litigated."); Linda Galler, The Tax Lawyer's Duty to the System, 16 Va. Tax Rev. 681, 687 (1997) (reviewing Bernard Wolfman et al., Ethical Problems in Federal Tax Practice (3d ed. 1995)) ("The notion of zealous representation of client interests is intuitive to law students . . ..”); see also Linda M. Beale, Tax Advice Before the Return: The Case for Raising Standards and Denying Evidentiary Privileges, 25 VA. TAx Rev. 583, 595 (2006) (speaking of "a social norm and standards of tax practice, including a client-centered ethical structure, that favor client advocacy and tax minimization over duty to the tax system").

${ }^{2}$ Model Rules of Prof'l Conduct R. 1.1 (2007), available at http://www.abanet.org/ $\mathrm{cpr} / \mathrm{mrpc} / \mathrm{mrpc} \_$toc.html.

${ }^{3} I d$. R. 1.3 .

${ }^{4} I d$. R. 1.6(a).

${ }^{5}$ Id. R. $1.7,1.9,1.18$.

${ }^{6} I d$. R. $1.3 \mathrm{cmt}$. 1; see also Restatement, supra note 1 , at $\$ 16 \mathrm{cmt}$. d (observing that such statements indicating that a lawyer should act "zealously" on behalf of her client "set[] forth a traditional aspiration"). For a discussion of several additional rules that impose duties that protect the client, see Anthony C. Infanti, The Ethics of Tax Cloning, 6 Fla. TAx Rev. 251, 315-16 (2003) [hereinafter Infanti, Tax Cloning].

${ }^{7}$ Model Rules of Prof' ' Conduct R. 1.2(d).

${ }^{8} I d$. R. 3.4(a).

${ }^{9} I d$.

${ }^{10} I d$. R. 3.4(b).

${ }^{11} I d$. R. 3.4(d). For a discussion of additional rules that protect the interests of third parties, see Infanti, Tax Cloning, supra note 6, at 315-19.

${ }^{12}$ Model Rules of Prof'l Conduct R. 3.3 cmt. 2. 
body acting in an adjudicative capacity," even if the information that must be revealed is otherwise subject to the duty to maintain client confidences. ${ }^{13}$

Likewise, it is generally_-though by no means universally_acknowledged that a tax lawyer owes a similar special duty to the tax system that may conflict with and constrain the duty that she owes to her clients. ${ }^{14}$ The American

${ }^{13} I d$. R. 1.0(m); see id. R. 3.3. For a discussion of additional rules that are designed to protect the integrity of the adjudicative process, see Infanti, Tax Cloning, supra note 6, at 315-17.

${ }^{14}$ E.g., Bernard Wolfman et al., Standards of Tax Practice $\$ 101.2$ (6th ed. 2004); Beale, supra note 1, at 595, 661; Mortimer M. Caplin, Responsibilities of the Tax AdviserA Perspective, 40 Taxes 1030, 1032 (1962); Frederic G. Corneel, Guidelines to Tax Practice Third, 57 Tax Law. 181, 187, 192-93 (2003) [hereinafter Corneel, Guidelines Third]; Frederic G. Corneel, Guidelines to Tax Practice Second, 43 TAx Law. 297, 301-02 (1990) [hereinafter Corneel, Guidelines Second]; Michael C. Durst, The Tax Lawyer's Professional Responsibility, 39 U. Fla. L. Rev. 1027, 1028-29, 1031 n.9, 1050 n.81 (1987); Richard Lavoie, Deputizing the Gunslingers: Co-opting the Tax Bar into Dissuading Corporate Tax Shelters, 21 Va. Tax Rev. 43, 79, 89-91 (2001) [hereinafter Lavoie, Gunslingers]; Richard Lavoie, Subverting the Rule of Law: The Judiciary's Role in Fostering Unethical Behavior, 75 U. Colo. L. Rev. 115, 190 (2004); John M. Maguire, Conscience and Propriety in Lawyer's Tax Practice, 13 Tax L. Rev. 27, 35-36, 44 (1957); Randolph E. Paul, The Responsibilities of the Tax Adviser, 63 Harv. L. Rev. 377, 381-82, 384, 386-88 (1950); Harold S. Peckron, Watchdogs That Failed to Bark: Standards of Tax Review After Enron, 5 Fla. Tax Rev. 853, 866-67, 901-03 (2002); J. Timothy Philipps, It's Not Easy Being Easy: Advising Tax Return Positions, 50 Wash. \& Lee L. Rev. 589, 589 \& n.2 (1993); Prescott, supra note 1, at 715, 772; Paul J. Sax, Lawyer Responsibility in Tax Shelter Opinions, 34 TAx Law. 5, 30, 38 (1980); Schizer, supra note 1, at 370; Randolph W. Thrower, Preserving the Integrity of the Federal Tax System, 33 N.Y.U. Ann. Inst. on Fed. Tax'n 707, 709-10 (1975); Dennis J. Ventry, Jr., Filling the Ethical Void: Treasury's 1986 Circular 230 Proposal, 112 Tax Notes (TA) 691, 694-95 (2006) [hereinafter Ventry, Filling the Ethical Void]; Dennis J. Ventry, Jr., Lowering the Bar: ABA Formal Opinion 85-352, 112 TAx Notes (TA) 69, 70 (2006) [hereinafter Ventry, Lowering the Bar]; Johnnie M. Walters, Ethical and Professional Responsibilities of Tax Practitioners, 17 Gonz. L. Rev. 23, 24, 25-26, 33, 35 (1981); Galler, supra note 1, at 687; Matthew C. Ames, Note, Formal Opinion 352: Professional Integrity and the Tax Audit Lottery, 1 Geo. J. Legal Ethics 411, 414-15, 427 (1987); Ann Southworth, Note, Redefining the Attorney's Role in Abusive Tax Shelters, 37 Stan. L. Rev. 889, 891, 908-12, 914, 918 (1985); see also Tanina Rostain, Sheltering Lawyers: The Organized Tax Bar and the Tax Shelter Industry, 23 YALE J. ON REG. 77, 82, 114, 119, 120 (2006) (explaining the organized tax bar's efforts to reign in corporate tax shelters, which were neither in the economic interests of the tax lawyers themselves or their clients, as an attempt to re-affirm tax lawyers' status as gatekeepers of the tax system and describing these lawyers as viewing themselves as having obligations to the tax system). Contra Mark H. Johnson, Does the Tax Practitioner Owe a Dual Responsibility to His Client and to the Government?-The Theory, 15 S. Cal. Tax Inst. 25 passim (1963); Camilla E. Watson, Tax Lawyers, Ethical Obligations, and the Duty to the System, 47 U. Kan. L. Rev. 847, 851, 871, 909 (1999); see Camilla E. Watson, Legislating Morality: The Duty to the Tax System Reconsidered, 51 U. Kan. L. Rev. 1197, 1197, 1236-37 (2003) (revisiting her earlier position in light of intervening events and concluding that "it is now painfully clear that relying on an ideological 'duty to the system' has not worked," but acknowledging that the notion that tax lawyers owe a special duty to the tax system is "the popular view among tax scholars"). 
Bar Association (ABA) appears to straddle the fence in this debate, providing aid and comfort to both sides. On the one hand, the ABA has formally adopted the view that tax compliance is often the first step in an adversarial process, ${ }^{15}$ providing justification for those who reject anything but undivided loyalty to the client in interactions with the Service. ${ }^{16}$ On the other hand, the ABA permits lawyers to draw on nonlegal considerations (for example, "moral, economic, social and political factors") ${ }^{17}$ when rendering advice to clients and further urges lawyers to participate "in activities for improving the law, the legal system or the legal profession," 18 thus opening the door for the view that tax lawyers actually have competing loyalties to their clients and to the tax system.

In any event, there is some intuitive appeal to the notion that a tax lawyer must balance the duty to her client against a countervailing duty to the tax

${ }^{15}$ ABA Comm. on Ethics and Prof'l Responsibility, Formal Op. 85-352 (1985) ("In many cases a lawyer must realistically anticipate that the filing of the tax return may be the first step in a process that may result in an adversary relationship between the client and the IRS."). This position presents a very slight step back from an earlier position that clearly equated preparation of a tax return with an adversarial proceeding. See ABA Comm. on Ethics and Prof'l Responsibility, Formal Op. 314 (1965). The position is clarified in the Report of the Special Task Force on Formal Opinion 85-352:

The Opinion does not state that the general ethical guidelines governing advocacy in litigation are determinative, or suggest that tax returns are adversarial proceedings. To the contrary, a tax return initially serves a disclosure, reporting, and self-assessment function. It is the citizen's report to the government of his or her relevant activities for the year. The Opinion says that because some returns, particularly aggressive ones, may result in an adversary relationship, there is a place for consideration of the ethical considerations regarding advocacy. Thus, the Opinion blends the ethical guidelines governing advocacy with those applicable to advising, from which the new ethical standard is derived.

Paul J. Sax et al., Report of the Special Task Force on Formal Opinion 85-352, 39 Tax Law. 635, 640 (1986); see also Beale, supra note 1, at 628-29 (describing ABA Formal Opinion 85-352 as "still treating the relationship between attorneys and the Service as adversarial"); Durst, supra note 14, at 1030-49 (describing ABA Formal Opinions 314 and 85-352, as well as the history behind the transition from the ABA's earlier to its later position on the nature of tax return preparation, and concluding that, "[o]n the whole, [ABA Formal Opinion 85-352] seems to reaffirm the view of the return as an adversarial document"); Prescott, supra note 1, at 719-20 ("The Committee began its reconsideration of the lawyer's duties as a tax return advisor by implicitly endorsing the conclusion of Formal Opinion 314 that the return preparation process should be treated as an adversarial proceeding and that the tax lawyer's duties are those of an advocate." (footnotes omitted)); Ventry, Lowering the Bar, supra note 14, at 70 ("By assuming an adversarial relationship, Opinion 85-352 reprised Opinion 314, which had identified the IRS as an adversarial party in its first sentence."); $i d$. at 74 (critiquing the assumption of an adversarial relationship between taxpayers and the Service in ABA Formal Opinion 85-352).

${ }^{16}$ Prescott, supra note 1, at 705 .

${ }^{17}$ Model Rules of Prof'l Conduct R. 2.1.

${ }^{18}$ Id. R. 6.1(b)(3). 
system. ${ }^{19}$ From the start, the taxpayer has a decided advantage over the government in tax matters merely by dint of the ability to self-assess her rightful share of the overall tax burden. Under our self-assessment system, the taxpayer has the advantage of: (1) being the only party with full knowledge of the relevant facts; (2) maintaining a great deal of control over whether-and, if so, how - those facts are shared with the government; and (3) knowing that the government lacks the resources to audit compliance with the tax laws in

${ }^{19}$ See Anthony C. Infanti, Eyes Wide Shut: Surveying Erosion in the Professionalism of the Tax Bar, 22 VA. TAx Rev. 589, 603-11 (2003) [hereinafter Infanti, Eyes Wide Shut].

Naturally, the duty to the tax system is not the sole countervailing consideration in determining the appropriate tax treatment for a transaction. A tax lawyer must also consider the applicability of civil or criminal penalties (or both) to a position taken on a tax return. See I.R.C. $\$ \$ 6694,7701$ (a)(36)(A) (respectively, tax return preparer penalties and definition of tax return preparer); Reg. $\$ 1.6694-1$ (b)(3) (indicating that an attorney who provides advice to a client with regard to the treatment of a significant item on a client's tax return can be considered a tax return preparer for purposes of this penalty); Reg. $\$ 301.7701-15$ (b) (stating a similar rule, which is incorporated by reference in section 6694(f)); Anthony C. Infanti, The Internal Revenue Code as Sodomy Statute, 44 Santa Clara L. Rev. 763, 790-800 [hereinafter Infanti, Sodomy Statute] (describing the civil and criminal penalties that may apply to lesbian and gay taxpayers). Some would argue that, when assessing the potential cost of these penalties, a "rational" actor would discount the nominal amount of these penalties to reflect the relatively low likelihood of detection, which, in practice, would render these penalties a relatively weak form of constraint. Alex Raskolnikov, Crime and Punishment in Taxation: Deceit, Deterrence, and the Self-Adjusting Penalty, 106 Colum. L. Rev. 569, 571, 576-77, 593-94 (2006); see also Beale, supra note 1, at 612 (describing the current era as being characterized by "low enforcement resources and an 'economically rational "audit lottery" discount" (quoting Robert A. Rizzi, Tax Shelters Invade: Corporate Transactions and the Anti-Shelter Crusade, CoRp. TAx'N, July-Aug. 2004, at 22)); Infanti, Sodomy Statute, supra, at $801 \& \mathrm{n} .133$ (indicating that the tax laws are underenforced, but nevertheless citing instances in which lesbian and gay taxpayers have been pursued by the Service).

In any event, my focus here is not on civil and criminal penalties, but on the duty to the tax system-despite the contention of some that it "is too slender a reed to support cooperation with the government." Schizer, supra note 1, at 371. In this regard, I disagree with those who paint tax lawyers as essentially amoral, rational economic actors who help the government only when it furthers their own (or their clients') interests and who surreptitiously work to defeat any obligation to help the government that does not serve their own (or their clients') interests by engaging in the most parsimonious of readings of those obligations. See id. at 342-45, 355-71; cf. Corneel, Guidelines Second, supra note 14, at 299 ("The firm expects each attorney involved in tax matters to adhere to these guidelines, accepting them not as technical rules of law to be avoided by the clever exercise of lawyerly skills, but rather as a guide to a satisfying professional life and to the building of a professional environment in which we can be comfortable in the knowledge that others in the firm bring to bear the same standards."). This reductionist portrait does not accurately depict many of the tax lawyers with whom I worked when in practice. I agree instead with those who argue against discounting the force of a lawyer's "internally generated allegiance to the public aspects of legal practice." David Wilkins, Who Should Regulate Lawyers?, 105 Harv. L. Rev. 799, 866 (1992). Indeed, as Wilkins notes, "[M]any students go to law school precisely because they seek a way of life that places public commitments at least on a par with the pursuit of private profit." Id. at 866 n.296. 
all but a small handful of cases. ${ }^{20}$ This combination of advantages creates an incentive for taxpayers either to avoid reporting questionable transactions at all or, if they must, to report them in a way that will not draw the attention of the Service. In this way, taxpayers can play the audit "lottery" with the confidence that, in all likelihood, their returns will escape scrutiny and, as a result, questionable positions taken on those returns will be confirmed by default. ${ }^{21}$ To superimpose unbridled loyalty to the client over these already hefty advantages would only seem to foster abuse of the tax system that will undermine its integrity and, eventually, erode its viability as a means of collecting the revenue upon which the functioning of our government depends.

Unfortunately, however, intuitive appeal often leads to unthinking application. ${ }^{22}$ Thus, a tax lawyer might be tempted to apply this conventional conceptualization of the duty to the tax system-that is, as a necessary temper for unbridled zealous advocacy - to the unconventional advice that she provides to her lesbian and gay clients. As explored more fully below, lesbians and gay men do not experience the tax system in the same way that heterosexuals do. In contrast to heterosexuals, lesbians and gay men are in the unique position of being the only group that is the object of both overt and covert invidious discrimination in the application of the tax laws. An important effect of this discrimination is to turn what is a tactical advantage in the hands of heterosexual taxpayers into the only defense-and, it is worth noting, a defense that often comes at the price of self-stigmatization-that lesbians and gay men

\footnotetext{
${ }^{20}$ See Prescott, supra note 1, at 711-13; see also Beale, supra note 1, at 636 ("Because of the Service's limited enforcement resources, the audit lottery remains a manageable risk for many sophisticated taxpayers. As a result, numerous transactions that the government would consider abusive likely remain obscured within a complex layer of business transactions and are never exposed to litigation.").

${ }^{21}$ Philipps, supra note 14 , at 612 . The author states:

The nature of the tax return audit process dictates that most returns will not be picked for audit. This means that a taxpayer who resolves all doubts in his own favor always has an advantage, because the return is not likely to be audited. In effect, this treatment decides almost all doubtful questions in favor of the taxpayer.
}

Id.; see Prescott, supra note 1, at 712-13.

${ }^{22}$ It is worth noting here that this Article is part of a larger project of employing a critical perspective to question and problematize distinctions and concepts in the tax policy literature that, on their face, seem normal, natural, or just plainly incontestable. See Anthony C. Infanti, A Tax Crit Identity Crisis? Or Tax Expenditure Analysis, Deconstruction, and the Rethinking of a Collective Identity, 26 Whittier L. Rev. 707 (2005) [hereinafter Infanti, Identity Crisis] (highlighting the artificiality of the mainstream/marginal distinction in the tax policy literature and drawing attention to the ways in which that distinction can be employed to ignore or discredit critical contributions to that literature); Anthony C. Infanti, Tax Equity, 55 Buff. L. Rev. 1191 (2008) [hereinafter Infanti, Tax Equity] (exploring how the core tax policy concept of equity can have negative effects on the contributions of critical tax scholars to the tax policy literature). 
have against an overreaching federal government. As a result, if a tax lawyer were to temper her advice to lesbian and gay clients in accordance with the conventional conceptualization of the duty to the tax system, she might not only undercut the effectiveness of these defenses, but also risk doing serious harm to her clients. In either case, the tax lawyer would have become an accomplice of the federal government in its invidious discrimination against her lesbian and gay clients.

This Article deconstructs ${ }^{23}$ the conventional conceptualization of the duty to the tax system in an effort to open the necessary ethical space for crafting an alternative view of that duty-one that better suits the representation of lesbian and gay clients. Precisely because of its conventionality, the common conceptualization of the duty to the tax system is an overweeningly heteronormative $^{24}$ one. By this, I mean that this conceptualization reflects "the largely unstated assumption that heterosexuality is the essential and elemental ordering principal of society." 25 Having been crafted with only heterosexuals in mind, the conventional conceptualization of the duty to the tax system reflects heterosexual taxpayers' considerable tactical advantages over the Service and posits a nearly constant tension between that duty and the tax lawyer's duty of zealous advocacy. In contrast, the alternative view that I lay out in this Article delineates a duty to the tax system that exists in harmony with, rather than opposition to, the duty of zealous advocacy. This alternative view allows a tax lawyer simultaneously to protect her lesbian and gay clients from harm and to discharge her obligation to safeguard the integrity of the tax system by actively preventing its abuse by an overreaching federal government.

\footnotetext{
${ }^{23}$ As I have explained at length elsewhere, "the term 'deconstruction' has multiple meanings in the legal academic literature." Infanti, Identity Crisis, supra note 22, at 746-47. As I use the term here, "deconstruction refers to 'a methodology, an interpretive tool' that 'is the brainchild of Jacques Derrida,' a French philosopher." Id. at 747 (quoting Vivian Grosswald Curran, Deconstruction, Structuralism, Antisemitism and the Law, 36 B.C. L. Rev. 1, 4, 6 (1994)). In particular, I primarily employ the deconstructionist technique of inverting hierarchical oppositions in this Article. See id. at 752-83 (discussing the inversion of hierarchies and providing numerous examples of this interpretive technique from both inside and outside the tax literature); see also Anthony C. Infanti, Tax Protest, "A Homosexual," and Frivolity: A Deconstructionist Meditation, 24 ST. Lous U. Pub. L. Rev. 21, 40-58 (2005) [hereinafter Infanti, Deconstructionist Meditation] (employing deconstructionist etymological analysis, a technique that I also employ in this article). That is, I attempt in this Article to show how the rationale underlying the conventional conceptualization of the duty to the tax system, which requires the privileging of the interests of the government over those of the individual taxpayer when the tax treatment of a transaction is uncertain, can actually be used to turn that conceptualization of the duty to the tax system on its head in the case of lesbian and gay taxpayers-resulting in the privileging of the interests of lesbian and gay taxpayers over those of the government when the tax treatment of their transactions is uncertain.

${ }^{24}$ See generally Nancy J. Knauer, Heteronormativity and Federal Tax Policy, 101 W. VA. L. Rev. 129 (1998).

${ }^{25} \mathrm{Id}$. at 133 .
} 
I have divided the remainder of this Article into four parts. Part II sketches the conventional conceptualization of the duty to the tax system and its relationship to a tax lawyer's duty of zealous advocacy. Part III offers a lesbian and gay perspective on the conventional conceptualization of the duty to the tax system. Part IV relaxes the assumption that all taxpayers are heterosexual and explain how the duty to the tax system and the duty of zealous advocacy can nicely coalesce in the representation of lesbian and gay taxpayers. Part V sets forth my brief concluding remarks.

\section{The Duty to the Tax System: The Heteronormative View}

This Part briefly describes the conventional conceptualization of the duty to the tax system. The first section summarizes the justifications that commentators offer for imposing a duty to the tax system on tax lawyers. The following section sketches the (admittedly, ambiguous) contours of that duty. Both sections underscore the tension between the duty to the tax system and the duty of zealous advocacy that is intrinsic to the heteronormative view of the tax world.

\section{A. Justifications for the Duty to the Tax System}

Commentators have offered a variety of justifications for imposing a duty to the tax system on tax lawyers. Some view the imposition of this duty as part of a mutually beneficial exchange transaction: "the tax system gives tax lawyers their livelihood, so they in turn owe a duty to nurture it." 26 Others view the duty as grounded in patriotism; that is, it arises out of "the gratitude that any citizen should feel for the freedom and security the U.S. government provides; if we feel grateful, we should want to preserve the government's lifeline, the tax system." ${ }^{27}$ In a similar (though less overtly patriotic) vein, yet other commentators argue that "it is a principal ethical obligation of the tax lawyer to devote attention, energy and time to our tax law and our tax system ... in order to avoid collapse of our governmental system."28

To render the duty more tangible and personally relevant, some commentators remind us that we all have a direct stake in our government and in the tax system that supports it: ${ }^{29}$

\footnotetext{
${ }^{26}$ Schizer, supra note 1 , at 370 .

${ }^{27} I d$.

${ }^{28}$ Walters, supra note 14 , at 24 . The author notes:
}

I am of the school that charges the tax lawyer with additional duties and responsibilities. Why is this so? In one sentence-our tax system is the very basic support for our democratic system of government and private enterprise, and the tax lawyer plays a major role in the effective functioning of our tax system.

Id. at 25-26.

${ }^{29}$ The following passage is quoted from Infanti, Eyes Wide Shut, supra note 19, at 607, with original footnotes altered to comport with this Article. 
Despite being referred to as a duty to the abstract and impersonal revenue "system," one commentator has envisaged the obligees of this duty as the more concrete and sympathetic class of "unrepresented citizens who ascribe value to a well-functioning tax system." ${ }^{30}$ All citizens have a general interest in ensuring the government's ability to fund itself. ${ }^{31}$ More immediately, however, each citizen also has an interest in ensuring that the burden of funding the government is borne by each taxpayer in accordance with the allocation prescribed by their democratically-elected [sic] representatives. ${ }^{32}$ After all, to the extent that one taxpayer is able to avoid a portion of her tax burden, that burden must be taken up by every other taxpayer. ${ }^{33}$

But a more common — and more plausible_-justification for imposing a duty to the tax system on tax lawyers relies upon the realities of the tax compliance and enforcement process: ${ }^{34}$

[T] he adversary in tax matters is always the government, which relies on self-assessment to collect taxes. ${ }^{35}$ Unlike other adversaries, who can be expected "to scrutinize critically the lawyer's statements," 36 the government lacks the resources to audit more than a small portion of the returns that are filed by taxpayers. ${ }^{37}$ Consequently, the tax lawyer may often be the ultimate arbiter of what the revenue laws require. ${ }^{38}$

In other words, the duty to the tax system serves to level the playing field between two unequally matched adversaries. It requires the tax lawyer, who is representing the relatively more powerful player in this match-up (that is, the taxpayer), to take account of the interests of the less powerful player (that is, the government) whenever she exercises discretion, as she inevitably does, ${ }^{39}$ in settling on the appropriate tax characterization of a transaction. ${ }^{40}$

\footnotetext{
${ }^{30}$ Southworth, supra note 14 , at 912 .
}

${ }^{31}$ Galler, supra note 1 , at 694.

${ }^{32} I d$.

${ }^{33}$ Walters, supra note 14, at 37 ("Under our self-assessment tax system, where each taxpayer is charged with returning and paying his fair share of our tax burden, any reduction, lawful or unlawful, impacts adversely on the tax burdens of every other American, including even the lawyer representing that taxpayer.").

${ }^{34}$ Please note that the passage that follows in the text above is quoted from Infanti, Eyes Wide Shut, supra note 19, at 606, with original footnotes altered to comport with this Article.

${ }^{35}$ Galler, supra note 1 , at 694.

${ }^{36}$ Durst, supra note 14 , at 1034.

${ }^{37} \mathrm{Id}$.; Walters, supra note 14, at 36; Galler, supra note 1, at 694-95.

${ }^{38}$ Durst, supra note 14, at 1035; Prescott, supra note 1, at 713-14; Southworth, supra note 14 , at 910-11.

39" [A] short training in tax law will convince the most stubborn of intellects that there is no such thing as words so plain that they do not have to be interpreted." Randolph E. Paul, Motive and Intent in Federal Tax Law, in Selected Studies in Federal Taxation: Second Series 255, 272 (Randolph E. Paul et al., eds. 1938); see also Philipps, supra note 14, at 590 ("Clients do not come to tax lawyers for expensive advice on easy questions. The lawyer normally must give advice where either the law itself or the application of the facts to the law is uncertain.").

${ }^{40} \mathrm{In}$ speaking of the representation of powerful corporate interests (e.g., savings and loans in the 1980s and Enron more recently) against the government, Susan Carle similarly argues: 
At first blush, this analogy to a game in which the taxpayer and the Service are adversaries may seem counterfactual. After all, aren't taxpayers, their tax lawyers, and the government all working toward the same end-namely, to determine the "correct" ${ }^{41}$ tax treatment of items reflected on the taxpayer's return? ${ }^{42}$ In theory, the answer to this question should be "yes." As commentators have observed, the relationship between taxpayers and the Service should remain cooperative until they reach the stage of litigation (or possibly on audit, but only if the revenue agent adopts an adversarial stance). ${ }^{43}$ In reality, however, the organized bar has staunchly defended the view that the relationship between taxpayers and the Service is adversarial-and not cooperative-in nature. ${ }^{44}$ Taxpayers reify this putative adversarial relationship and signal the start of the game whenever they attempt to press their superior starting position to maximum advantage. The only reason for taxpayers to play this game is that they "fear scrutiny by the Service." ${ }^{55}$ This fear of scrutiny

indicates that they are taking their tax reporting position based on a belief that the Service will not discover the transaction rather than on a good faith belief in its merits. This is counter to their duty as taxpayers to fairly make their tax situation known to the Service under the self-assessment system. ${ }^{46}$

The reason the lawyers should have been less zealous in their advocacy for their clients in these situations is not simply that they should have sought to preserve the purposes of law or morality, but also because, in context (vis-à-vis government agencies with relatively limited personnel resources for investigation of corporate wrongdoing), these lawyers' corporate clients were, in some respects, the more powerful entity. At the very least, these clients had much more equivalency of resources in terms of their ability to evade detection of wrongdoing by government agencies engaged in compliance monitoring and civil enforcement actions.

Susan D. Carle, Power as a Factor in Lawyers' Ethical Deliberation, 35 Hofstra L. Rev. 115, 161 (2006).

${ }^{41}$ See I.R.C. $\$ 6065$ (requiring returns to be signed under penalty of perjury); Reg. $\$ \$$ 1.446-1(a)(4) ("Each taxpayer is required to make a return of his taxable income for each taxable year and must maintain such accounting records as will enable him to file a correct return.") (emphasis added), 1.461-1(a)(3) ("Each year's return should be complete in itself, and taxpayers shall ascertain the facts necessary to make a correct return.") (emphasis added); Internal Revenue Serv., Dep't of Treasury, Form 1040: U.S. Individual Income Tax RETURN 2 (2006) ("Under penalties of perjury, I declare that I have examined this return and accompanying schedules and statements, and to the best of my knowledge and belief, they are true, correct, and complete.") (emphasis added).

${ }^{42}$ Richard Lavoie, Making a List and Checking It Twice: Must Tax Attorneys Divulge Who's Naughty and Nice?, 38 U.C. Davis L. Rev. 141, 198 (2004) [hereinafter Lavoie, Making a List].

${ }^{43}$ See Beale, supra note 1, at 648; Prescott, supra note 1, at 730-31; Southworth, supra note 14, at 910 n.122.

${ }^{44}$ See Dennis J. Ventry, Jr., Raising the Ethical Bar for Tax Lawyers: Why We Need Circular 230, 111 TAX Notes (TA) 823, 828-29 (2006) [hereinafter Ventry, Raising the Ethical Bar] (describing how tax controversy norms won out over tax planning norms in the debate over the ethical obligations of tax lawyers); see also supra note 15 and accompanying text.

${ }^{45}$ Lavoie, Making a List, supra note 42, at 199.

${ }^{46} I d$. 
The duty to the tax system intervenes to remind tax lawyers that: (1) tax compliance is not supposed to be a zero-sum game; and (2) they, like all lawyers, have an ethical duty not to undermine the integrity of the legal system of which they form a part. ${ }^{47}$ Given the realities of the tax compliance and enforcement process, it might therefore be more accurate to say that, when the tax lawyer enters gray areas of tax characterization, she is asked to privilege her duty to the tax system over her duty of zealous advocacy in an attempt to right the relationship between the taxpayer and the Service. Viewed in this light, the duty to the tax system serves as a check on the more powerful party (here, the taxpayer) in order to prevent her from riding roughshod over the less powerful party (here, the Service) to the great detriment of the tax system - and, vicariously, other taxpayers.

The notion that the duty to the tax system rights the relationship between the taxpayer and the Service-and thereby fosters confidence in, and shores up, our self-assessment system of taxation-underlies the Treasury Department's own articulation of the justification for this duty: ${ }^{48}$

While it is generally agreed that a practitioner owes a client competence, loyalty and
confidentiality, it also is recognized that a practitioner has responsibilities to the tax
system as well. In the normal practitioner-client relationship, both responsibilities
are recognized and carried out. However, there are situations when this is difficult.
In those situations, the practitioner is required to decide which obligation prevails
and, in so doing, may correctly conclude that the obligation to the tax system is
paramount. To this end, the ability of the IRS to accomplish its mission efficiently
and effectively depends on reliance on tax practitioners to be fair and honest in their
dealings with the IRS and to foster confidence by their clients in our tax system and
in tax compliance.

The area of tax return preparation and advice given with respect to positions on tax returns clearly reflects a practitioner's dual responsibility. A tax return is not a submission in an adversary proceedings [sic]. Rather, the tax return serves a disclosure, reporting and self-assessment function. It is a citizen's report to the government of his or [sic] relevent [sic] activities for the year. To serve its disclosure and assessment function, a tax return must be [sic] provide a fair report of matters affecting tax liability. The complexities of the tax and the limited number of tax return examinations the IRS is able to perform impose a substantial burden upon the government. Hence, the representations made on tax returns must accurately reflect the facts, and positions taken on tax returns must be supportable by the law. A practitioner, during an engagement with a taxpayer-client, has an affirmative duty to assure that these occur. ${ }^{48}$

${ }^{47}$ See supra notes $12-13$ and accompanying text. For a more recent discussion that strikes a similar chord, see Beale, supra note 1, at 630-33.

${ }^{48}$ Please note that the passage that follows in the text above is quoted from Infanti, Eyes Wide Shut, supra note 19, at 606, with original footnotes altered to comport with this Article.

${ }^{49}$ Tax Practitioners, 51 Fed. Reg. 29,113, 29,113 (Aug. 14, 1986) (proposing changes to 31 C.F.R. $\$ \$ 10.22,10.34$ ), proposed rules withdrawn, Regulations Governing the Practice of Attorneys, Certified Public Accountants, Enrolled Agents, and Enrolled Actuaries Before the Internal Revenue Service, 57 Fed. Reg. 46,356, 46,356 (Oct. 8, 1992). For the history behind these proposed regulations, see Ventry, Filling the Ethical Void, supra note 14. 
This passage also raises the issue of the precise nature of the duty that tax lawyers owe to the tax system, providing us with a nice segue into a discussion of the contours of that duty in the next section.

\section{B. Contours of the Duty to the Tax System}

Commentators also take divergent views concerning the precise nature of the tax lawyer's duty to the tax system. Some commentators see the duty to the tax system as having a direct impact on the attorney-client relationship, while others see it as entailing special duties for the tax lawyer as a citizen. I discuss each of these views separately below.

\section{A Duty that Directly Impacts the Attorney-Client Relationship}

Many commentators share the Treasury Department's view of this duty and see it as a helpful counterweight to the lawyer's duty of zealous advocacy: ${ }^{50}$

The tax lawyer's duty to the revenue system has been conceptualized as requiring her to "balance the immediate demands of [her] clients against the public's interest in a sound tax system which operates in accord with policy judgments reached through a democratic process." ${ }^{51}$ For example, in the tax planning context, the goal is to strike an appropriate balance between "excessive conservatism and reckless optimism." ${ }^{52}$ If a tax lawyer's advice is excessively conservative, she risks "depriving the client of tax benefits to which the client is legally entitled." 53 If, on the other hand, a tax lawyer's advice is excessively optimistic, she may not only aid her client in shirking all or a portion of the client's "rightful share of taxation," but may also erode the overall level of compliance with the tax system (and, ultimately, reduce or eliminate the effectiveness of the tax as a source of government revenue) by contributing to a general sense among taxpayers that "others are avoiding their proper shares of taxation." 54

And, in an important step toward righting the relationship between the taxpayer and the government, it seems that the tax lawyer should undertake the task of striking an appropriate balance between excessive conservatism and reckless optimism without factoring in the actual likelihood that the Service will detect and audit the position that her advice concerns. ${ }^{55}$

\footnotetext{
${ }^{50}$ The following passage is quoted from Infanti, Eyes Wide Shut, supra note 19, at 606-07, with original footnotes altered to comport with this Article.

${ }^{51}$ Galler, supra note 1 , at 693.

${ }^{52}$ Durst, supra note 14, at 1028.

${ }^{53} I d$.

${ }^{54} I d$.

${ }^{55}$ See Ames, supra note 14, at 428 ("The lawyer must therefore clearly explain to the client that society is relying on the taxpayer's honesty, and that the lawyer's integrity requires him or her to insist on that honesty."); id. at 429 (urging a revision of ABA Formal Opinion 85-352 to clearly provide that, " $[\mathrm{w}]$ hen preparing a return or giving advice, the lawyer must always assume the return will be audited"); $c f$. Reg. $\$ \$ 1.6662-4(\mathrm{~d})(2)$ ("The possibility that a return will not be audited or, if audited, that an item will not be raised on audit, is not relevant in determining whether the substantial authority standard (or the reasonable basis standard) is satisfied."); 1.6694-2(b)(1) ("In making this determination [that a position has a realistic possibility of being sustained on its merits], the possibility that the position will not be challenged
} 
Where the application of the tax laws is clear, striking the balance between excessive conservatism and reckless optimism is easy. In that case, the tax lawyer can discharge both her duty to the tax system and the duty to her client simply by advising the taxpayer to pay the "correct" amount of tax. ${ }^{56}$ More commonly, however, the "correct" amount of tax is unclear and striking the balance becomes difficult because the tax lawyer's duties to the tax system and to her client conflict with each other. ${ }^{57}$ As a result, a tax lawyer does not ordinarily experience these two duties as a harmonious whole drawing her ineluctably toward helping the client report the "correct" amount of tax; rather, she experiences them as opposing forces that pull her in two entirely different directions, one client-regarding and the other public-regarding.

When conceptualized in this way, the contours of the duty to the tax system are inherently ambiguous ${ }^{58}$ and naturally fraught with difficult ethical questions that will require the lawyer to bring her own moral judgment to bear if she hopes to resolve them. ${ }^{59}$ But while uncomfortable for the tax lawyer,

by the Internal Revenue Service (e.g., because the taxpayer's return may not be audited or because the issue may not be raised on audit) is not to be taken into account.") (please note that I.R.C. $\$ 6694$ was recently amended by the U.S. Troop Readiness, Veterans' Care, Katrina Recovery, and Iraq Accountability Appropriations Act, Pub. L. No. 110-28, \$ 8246(b), 121 Stat. 112, 203 (2007), to require an increased level of confidence in return positions, and this regulation does not yet reflect that revised standard); 31 C.F.R. $\$ 10.34(\mathrm{~d})(1)$ (in determining whether a position has a realistic possibility of being sustained on its merits, "[ $t$ ] he possibility that a tax return will not be audited, that an issue will not be raised on audit, or that an issue will be settled may not be taken into account"); ABA Comm. on Ethics and Prof'l Responsibility, Formal Op. 85-352 (1985) (indicating that the prior standard applicable to tax lawyers had "been construed by many lawyers to support the use of any colorable claim on a tax return to justify exploitation of the lottery of the tax return audit selection process," and adopting in its stead a standard that permits a lawyer to advise a taxpayer to take a return position only if "there is some realistic possibility of success if the matter is litigated") (emphasis added). But see Joel S. Newman, The Audit Lottery: Don't Ask, Don't Tell?, 86 Tax Notes (TA) 1438 (2000) (arguing that tax lawyers should be able to inform their clients about the Service's audit rate; however, if the taxpayer acts on that advice by taking an undisclosed return position that does not meet the realistic possibility of success standard, then he asserts that the attorney must withdraw from the representation to avoid penalties; moreover, if apprising the client of the audit rate would automatically subject a lawyer to penalties, then he would not encourage the attorney to do so).

${ }^{56}$ WOLFMAN ET AL., supra note $14, \$ 101.2$.

${ }^{57} \mathrm{Id}$.

${ }^{58}$ See id.; Durst, supra note 14, at 1052; Maguire, supra note 14, at 44; Watson, Legislating Morality, supra note 14, at 1207; see also Galler, supra note 1, at 687-88 (discussing how "duty to the system" can actually refer to several different distinct duties).

${ }^{59}$ See Model Rules of Prof'l Conduct pmbl. g 9:

In the nature of law practice, however, conflicting responsibilities are encountered. Virtually all difficult ethical problems arise from conflict between a lawyer's responsibilities to clients, to the legal system and to the lawyer's own interest in remaining an ethical person while earning a satisfactory living. The Rules of Professional Conduct often prescribe terms for resolving such conflicts. Within the framework of these Rules, however, many difficult issues of professional discretion can arise. Such issues 
this ambiguity may be part of what makes the duty to the tax system such a potentially effective counterweight to the duty of zealous advocacy. Much like the ambiguity that is inherent in the judicially created anti-abuse doctrines (for example, substance over form, sham transaction, and step transaction), the ambiguity inherent in the duty to the tax system works to the advantage of the Service by creating a "penumbra of uncertainty" that should dissuade conscientious tax lawyers from advising taxpayers to undertake "transactions likely to fall into the gray zone." ${ }^{60}$ In other words, when the tax lawyer finds herself dealing with questionable tax characterizations in this gray zone, we expect her to privilege her duty to the tax system over her opposing duty of zealous advocacy, essentially resolving doubts against the taxpayer and in favor of the Service.

When a tax lawyer enters the gray zone, the duty to the tax system will sometimes lead to a sub rosa shaping of the advice that she provides to her client, with the lawyer silently ruling out certain options because they cross the line into what she feels is too risky territory. In other situations, the tax lawyer will not completely rule out an option before advising her client, but the duty to the tax system will cause the lawyer to attempt to dissuade the client from pursuing that option in favor of another that the lawyer feels is less risky. In either case, the tax lawyer is discharging what William Simon has termed her "professional duty of reflective judgment." ${ }^{11}$ Taking into account the realities of the enforcement process, the tax lawyer is exercising her ethical discretion in the manner that "seem[s] [to her] most likely to promote justice." ${ }^{2}$ For purposes of this Article, it is worth noting that promoting justice here usually means privileging the duty to the tax system over the duty of zealous advocacy.

Compounding the general ambiguity of this formulation of the duty to the tax system is the fact that the contours of the duty can also shift with the changing context of a tax lawyer's representation of her client. That is to say, the duty that a tax lawyer owes to the tax system can vary depending on whether she is engaged in general tax planning or return preparation,

must be resolved through the exercise of sensitive professional and moral judgment guided by the basic principles underlying the Rules. These principles include the lawyer's obligation zealously to protect and pursue a client's legitimate interests, within the bounds of the law, while maintaining a professional, courteous and civil attitude toward all persons involved in the legal system.

${ }^{60}$ Lavoie, Gun Slingers, supra note 14, at 48.

${ }^{61}$ William H. Simon, Ethical Discretion in Lawyering, 101 Harv. L. Rev. 1083, 1083 (1988).

${ }^{62} I d$. at 1090; see also id. at 1091, 1096-1107. 
representing her client on audit, or representing her client in litigation. ${ }^{63}$ For example, many commentators express the view that any duty to the tax system ends as soon as a tax matter reaches litigation because, at that point, the duty to see to the proper and effective administration of the tax laws shifts to the court. ${ }^{64}$

\section{A Duty that Entails a "Public Responsibility"}

Some commentators view the duty to the tax system as entailing a certain "public responsibility." ${ }^{65}$ As Randolph Paul has put it, the tax lawyer "is a citizen as well as a tax adviser. [She] is more than the ordinary citizen; [s] he is a specially qualified person in one of the most important areas of the public interest." ${ }^{66}$ Because of her specialized knowledge, a tax lawyer has a duty to engage in activities-for example, "speaking, writing, appearing before committees" - that aim to produce a "better" tax system, one "that raises the necessary revenue and at the same time distributes the required tax burden in a way which treats alike those who are similarly situated." ${ }^{67}$ Certain of these

${ }^{63}$ Even the Model Rules recognize that a lawyer may play one or more of a number of different roles that entail different obligations:

As a representative of clients, a lawyer performs various functions. As advisor, a lawyer provides a client with an informed understanding of the client's legal rights and obligations and explains their practical implications. As advocate, a lawyer zealously asserts the client's position under the rules of the adversary system. As negotiator, a lawyer seeks a result advantageous to the client but consistent with requirements of honest dealings with others. As an evaluator, a lawyer acts by examining a client's legal affairs and reporting about them to the client or to others.

Model Rules of Prof'L Conduct pmbl. g 2; see Prescott, supra note 1, at 703-04.

${ }^{64}$ E.g., Caplin, supra note 14, at 1033; Corneel, Guidelines Second, supra note 14, at 299; Ventry, Raising the Ethical Bar, supra note 43, at 828-29; Walters, supra note 14, at 33; Ames, supra note 14, at 415; see also Sax et al., supra note 15, at 636 (indicating that ABA Formal Opinion 85-352 does not address either a tax lawyer's ethical duties in negotiations and settlements with the Service or in tax litigation, thus lending credence to the notion that different ethical duties attend these different roles); Corneel, Guidelines Third, supra note 14, at 183 (excluding ethical rules relating to litigation from the scope of the project because those rules are the same as apply to other litigation, implying that tax planning, return preparation, and audit representation and administrative appeals are contexts that involve different ethical considerations); Galler, supra note 1, at 697-98 (describing how a tax lawyer's duty to the government itself_-as adversary or potential adversary_changes depending on whether the lawyer is serving in the role of advocate and adviser at the return preparation stage or is serving solely in the role of advocate at the litigation stage).

${ }^{65}$ Caplin, supra note 14 , at 1032.

${ }^{66}$ Paul, supra note 14 , at 386.

${ }^{67}$ Id. at 386-87; see Corneel, Guidelines Second, supra note 14, at 301 ("In addition to representing our clients, we should also seek to contribute to improvement of the tax laws and their administration."); Walters, supra note 14, at 25 ("Even among those lawyers who have taken the position that the tax practitioner does not owe a dual responsibility, to his client and to the Government, there is a recognition that the tax practitioner should face up to some responsibility in the development and effective operation of our tax system."); see also Johnson, supra note 14, at 35-37 (exploring the various avenues open to tax lawyers for shaping the law outside of the client context). 
commentators, including Paul, seem to eschew the notion that the duty to the tax system can directly impact the attorney-client relationship and instead confine it solely to this public responsibility ${ }^{68}$ However, others seem to view the tax lawyer's public responsibility as a natural adjunct to fulfilling her duty to the tax system within the individual attorney-client relationship. ${ }^{69}$

Notwithstanding the importance of this public aspect of the duty to the tax system, my primary focus in this Article is on the potential impact of the duty to the tax system on the individual attorney-client relationship. I am trying to reach the significant subset of tax lawyers (myself included) who allow the duty to the tax system to, at some level, influence the advice that they render to clients when the "correct" amount of tax is unclear. ${ }^{70}$ Thus, maintaining the focus on this aspect of the duty to the tax system, I will now turn to the task of providing a lesbian and gay perspective on the conventional conceptualization of the duty to the tax system.

\section{The Duty to the Tax System: A Lesbian and Gay Perspective}

Being grounded in the realities of the tax compliance and enforcement process, the conventional conceptualization of the duty to the tax system revolves around the expected relationship between the taxpayer and the Service. Conventionally, the taxpayer and the Service are initially presumed to be cooperatively striving toward the same end: the correct tax treatment of items on the taxpayer's return. The only reason for a taxpayer to press her natural tactical advantages over the Service would be to take questionable (that is, arguably incorrect) positions on her return that she does not wish the Service to detect and audit. Given the real danger of the taxpayer upsetting the presumptively cooperative relationship with the Service by treating it as an adversarial one, we attempt to right the relationship between the taxpayer and the Service by imposing a duty to the tax system on the taxpayer's lawyer. By righting the relationship in this way, we are able to maintain the integrity of the tax system and to preserve taxpayers' confidence in the system.

Paul's statement in the text above makes an oblique reference to the tax policy concept of "horizontal equity" (i.e., treating those with equal incomes equally). For a deconstruction of this concept and critique of its insidious influence on tax scholarship, see Infanti, Tax Equity, supra note 22.

${ }^{68}$ See Paul, supra note 14 , at 386.

${ }^{69}$ See Walters, supra note 14, at 24-25.

${ }^{70}$ Watson, Legislating Morality, supra note 14, at 1213. The author notes:

If there is a discrete duty to the tax system, the public's interest in ensuring that the federal tax system operates efficiently and fairly should be paramount, and questionable positions ideally should be resolved in favor of the government. Doubtless, there are some practitioners with very high standards who operate under this assumption. But this certainly is not true across the board.

Id. (footnote omitted). 
A lesbian and gay perspective on the conventional conceptualization of the duty to the tax system seemingly requires a trip through the looking-glass. ${ }^{71}$ For lesbians and gay men, each of the key features of the conventional view of the relationship between taxpayers and the Service that underpins the duty to the tax system is turned squarely on its head. As I will explain more fully below, the relationship between the Service and lesbian and gay taxpayers does not begin from a baseline of cooperation, but from a baseline of antagonism. Far from working cooperatively toward the end of determining the correct tax treatment of items on the taxpayer's return, the government has generally refused to provide meaningful guidance on the tax treatment of same-sex couples. And, in the rare instance when it has spoken, the Service's guidance has not necessarily aimed at a fair and honest application of the tax laws. Indeed, recent guidance appears to be driven more by ideology than by concern with the correct application of the tax laws to same-sex couples. Further compounding this adversarial turn is the reversal of the conventional power differential between the taxpayer and the Service in the case of lesbians and gay men. Instead of the taxpayer starting out with a decided advantage over the Service, the Service begins with a decided advantage over lesbian and gay taxpayers, who have been placed on the defensive by the government's studied silence on the tax treatment of same-sex couples. Moreover, the Service has pressed its advantages over lesbian and gay taxpayers to the point of overreaching.

In the following two sections of this Part, I will explore how this reversal comes about. We will see that it stems from the unique position that lesbians and gay men occupy as the only victims of both overt and covert invidious discrimination in the application of the tax laws. In the final section of this Part, we will consider the predicament that lesbians and gay men can face when the conventional conceptualization of the duty to the tax system is applied to their decidedly unconventional relationship with the Service.

\section{A. Overt Invidious Discrimination in the Application of the Tax Laws}

Overtly, Congress engaged in invidious discrimination against lesbians and gay men when it enacted the Defense of Marriage Act (DOMA). ${ }^{72}$ Section three of DOMA provides that:

\footnotetext{
${ }^{71}$ See generally Lewis Carroll, Through the Looking-Glass and What Alice Found There, in Lewis Carroll, Alice's Adventures in Wonderland \& Through the Looking Glass 119 (Signet Classic ed. 2000) (1871).

${ }^{72}$ Defense of Marriage Act, Pub. L. No. 104-199, 110 Stat. 2419 (1996). For a succinct argument that DOMA is unconstitutional on equal protection grounds because, out of antigay animus, Congress singled out lesbians and gay men for the imposition of an inferior legal status, see Evan Wolfson \& Michael F. Melcher, The Supreme Court's Decision in Romer v. Evans and Its Implications for the Defense of Marriage Act, 16 QuinNiPIAC L. Rev. 217 (1996).
} 
In determining the meaning of any Act of Congress, or of any ruling, regulation, or interpretation of the various administrative bureaus and agencies of the United States, the word "marriage" means only a legal union between one man and one woman as husband and wife, and the word "spouse" refers only to a person of the opposite sex who is a husband or a wife. ${ }^{73}$

Consequently, the federal government treats same-sex and different-sex relationships differently for tax purposes, even when state governments- the traditional arbiters of marital status for federal tax purposes ${ }^{74}$ - place those relationships on the same legal plane. ${ }^{75}$

As of this writing, six states have placed same-sex relationships on the same legal plane as different-sex relationships: Massachusetts has extended the right to marry to same-sex couples and California, Connecticut, New Jersey, New Hampshire, Oregon, and Vermont have created alternative regimes (whether labeled civil union or domestic partnership) that entail all of the rights and obligations of marriage. ${ }^{76}$ Same-sex couples who marry or enter into a civil union or domestic partnership in one of these states are therefore treated

Of course, DOMA's constitutionality has been assailed on a number of other grounds as well. See, e.g., Mark Strasser, Baker and Some Recipes for Disaster: On DOMA, Covenant Marriages, and Full Faith and Credit Jurisprudence, 64 Brook. L. Rev. 307 (1998) (arguing that the Full Faith and Credit Clause and Due Process Clause prohibit Congress from enacting DOMA); Mark Strasser, Ex Post Facto Laws, Bills of Attainder, and the Definition of Punishment: On DOMA, the Hawaii Amendment, and Federal Constitutional Constraints, 48 Syracuse L. Rev. 227 (1998) (arguing that DOMA violates the Bill of Attainder Clause); Mark Strasser, Loving the Romer out for Baehr: On Acts in Defense of Marriage and the Constitution, $58 \mathrm{U}$. PITT. L. Rev. 279 (1997) (arguing that enactment of DOMA exceeds Congress's power under the Full Faith and Credit Clause, violates the right to interstate travel, and does not meet the relevant standard for displacing state domestic relations law).

${ }^{73} 1$ U.S.C. $\$ 7$ (2007).

74"We agree with the government's argument that under the Code a federal court is bound by state law rather than federal law when attempting to construe marital status." Boyter v. Commissioner, 668 F.2d 1382, 1385 (4th Cir. 1981); see I.R.C. $\$ 7703$.

${ }^{75}$ Infanti, Sodomy Statute, supra note 19, at 781 n.32. For those who might counter that unmarried different-sex couples are actually in the same position as same-sex couples for federal tax purposes, I have explained elsewhere:

Unmarried heterosexual couples are likewise treated as no more than tax strangers to each other. Because they share the same status, unmarried heterosexual couples are subject to the same uncertainties and the same recordkeeping and reporting requirements that apply to gay and lesbian couples, which are described more fully in the text below. Unmarried heterosexual couples do, however, have one privilege that gay and lesbian couples do not- the privilege to choose to get married, have that marriage recognized by the federal government, and avoid all of these problems.

Id.

${ }^{76}$ Cal. Fam. Code $\$ 297.5$ (West 2007); Conn. Gen. Stat. $\$ 46 b-38 n n(2007) ;$ N.H. Rev. Stat. Ann. \$\$ 457-A:1-6 (2008); N.J. Rev. Stat. \$37:1-31 (2007); Vt. Stat. Ann. tit. 15, \$ 1204 (2006); 2007 Or. Laws Adv. Sh. No. 99 (Lexis) (effective Jan. 1, 2008); Opinions of the Justices to the Senate, 802 N.E.2d 565, 569 (Mass. 2004); Goodridge v. Dep't of Pub. Health, 798 N.E.2d 941, 955-57 (Mass. 2003). 
the same as married different-sex couples for state tax purposes, but they are treated as "single" strangers for federal tax purposes. ${ }^{77}$ As Nancy Knauer has explained, this differential tax treatment was not an accident; rather, it was an act of intentional and purposeful discrimination against lesbians and gay men:

The exclusion of same-sex couples from the marital provisions is intentional. As a result, there is nothing hidden or covert about the heterosexist bias of the tax code. There is no neutral principle at work. The rationale for the exclusion is not that same-sex couples do not pool their resources like opposite-sex married couples. Instead, the rationale for the exclusion is based on the beliefs that a same-sex couple is not a family, that no civilized society has ever countenanced such unions, and that our Judeo-Christian heritage forbids them. ${ }^{78}$

Through the enactment of DOMA, Congress has stigmatized lesbians and gay men "by branding their relationships inferior to those of straight couples. In effect, the Code at once embodies and perpetuates societal prejudice, discrimination, and hostility toward gays and lesbians by giving such activity the imprimatur of the federal government." ${ }^{79}$ As we will see more clearly in the next section, Congress has clearly marked lesbians and gay men as appropriate targets for hostile treatment by the Service—and even the courts—in tax matters. ${ }^{80}$

${ }^{77}$ Conn. Gen. Stat. $\$ 46 b-38 p p$ (2007); N.H. Rev. Stat. Ann. $\$ 457-A: 6$ (2008); N.J. Rev. Stat. \$37:1-32(n) (2007); Vt. Stat. Ann. tit. 15, \$1204(e)(14) (2006); Vt. Stat. AnN. tit. 32, \$5812; 2006 Cal. Legis. Serv. ch. 802 (S.B. 1827) (West); 2007 Or. Laws Adv. Sh. No. 99, $\$ \$ 9$ 9(8), 11 (Lexis) (effective Jan. 1, 2008); Dep't of Revenue, Commonwealth of Mass., Tech. Info. Rel. No. 04-17 (July 7, 2004); see infra text accompanying note 82.

From a procedural perspective, however, same-sex couples are often saddled with additional or more complex state tax reporting obligations because many states pattern their own income taxes after the federal income tax, which mandates separate (i.e., "single") filing for same-sex couples. See Catherine Martin Christopher, Note, Will Filing Status Be Portable? Tax Implications of Interstate Recognition of Same-Sex Marriage, 4 Pitt. TAx Rev. 137 (2007).

${ }^{78}$ Knauer, supra note 24, at 233; see also id. at 190 ("Numerous members of Congress returned again and again to the cost of providing federal benefits to same-sex partners. The effect of DOMA on the marital provisions of the tax code was not an unintended consequence."); H.R. Rep. No. 104-664, at 11 n.40 (1996), as reprinted in 1996 U.S.C.C.A.N. 2905, 2915 (referencing the prepared statement of Lynn D. Wardle, Professor of Law, Brigham Young University School of Law); Defense of Marriage Act: Hearing on H.R. 3396 Before the H. Subcomm. on the Constitution of the Comm. on the Judiciary, 104th Cong. 171 (1996) (prepared statement of Lynn D. Wardle) (specifically enumerating tax benefits as being among the federal benefits that would have to be extended to same-sex couples if a state were to legalize same-sex marriage).

${ }^{79}$ Infanti, Sodomy Statute, supra note 19, at 802.

${ }^{80}$ See Infanti, Deconstructionist Meditation, supra note 23, at 31-40 (describing the courts' treatment of Robert Mueller in his challenges to the application of the tax laws to lesbians and gay men). 


\section{B. Covert Invidious Discrimination in the Application of the Tax Laws}

In some situations, the tax effects of DOMA — as written by Congress and enforced by the Service-are clear. ${ }^{81}$ For example, it is clear that DOMA prohibits same-sex couples who have married in Massachusetts or entered into a civil union or domestic partnership in California, Connecticut, New Jersey, New Hampshire, Oregon, or Vermont from checking the "Married filing jointly" box under "Filing Status" on their federal income tax returns. ${ }^{82}$ In fact, in response to a letter from a conservative, "pro-family" organization urging it to investigate and prosecute any same-sex couples who might attempt to file joint federal income tax returns, the Service summarized its position on the ineligibility of same-sex couples for the marital provisions in the Code:

Even though a state may recognize a union of two people of the same sex as a legal marriage for the purposes within that state's authority, that recognition has no effect for purposes of federal law. A taxpayer in such a relationship may not claim the status of a married person on the federal income tax return. ${ }^{83}$

Consequently, it is equally clear that same-sex couples cannot claim the benefit of nonrecognition treatment for transfers between spouses under the income tax or the benefit of the gift and estate tax marital deductions, which, when taken together, allow spouses to transfer property within the couple tax-free. ${ }^{84}$

In many important areas, however, the tax treatment of same-sex couples has been left quite murky. Two factors contribute greatly to this murkiness. First, DOMA only tells same-sex couples that they may not look to the rules applicable to married couples for guidance; it says absolutely nothing about how the Code should be applied to them:

[D] uring the debate over DOMA, Congress debated whether same-sex couples should be spouses and never considered what default rules might apply to them if they are not treated as spouses. Thus, the message from Congress, as currently embedded in the tax laws, is that same-sex couples are not worthy of spousal treatment and, furthermore, their treatment under the tax laws is not even worthy of discussion. ${ }^{85}$

\footnotetext{
${ }^{81}$ See supra note 72 for a sampling of the litany of arguments why DOMA is unconstitutional.

${ }^{82} 1$ U.S.C. $\$ 7$ (2007) (“[T]he word 'marriage' means only a legal union between one man and one woman as husband and wife ....”).

${ }^{83}$ Letter from the Service to Eugene A. Delgaudio, President, Public Advocate of the United States, Inc. (June 14, 2004), available at http://www.publicadvocateusa.org/news/article. php?article $=121$. For further background on this exchange of letters, see Infanti, Deconstructionist Meditation, supra note 23, at 22-23.

${ }^{84}$ See 1 U.S.C. $\$ 7$ (2007) ("the word 'spouse' refers only to a person of the opposite sex who is a husband or a wife"); I.R.C. $\$ \$ 1041,2056,2523$ (applying only to transfers to a "spouse").

${ }^{85}$ Patricia A. Cain, Heterosexual Privilege and the Internal Revenue Code, 34 U.S.F.L. Rev. 465, 493 (2000) [hereinafter Cain, Heterosexual Privilege].
} 
Second, after the enactment of DOMA, Congress and the Service have held true to this latter message. They have utterly failed to provide meaningful guidance on how the Code should be applied to same-sex couples, ${ }^{86}$ sometimes even in the face of direct pleas for such guidance from conscientious taxpayers. ${ }^{87}$

But, like nature, the Code abhors a vacuum. Accordingly, the void created by the federal government's studied silence regarding the tax treatment of same-sex couples did not last long-it quickly swelled with some profoundly troubling tax issues. As described below, one of the starkest illustrations of this phenomenon concerns the tax treatment of same-sex couples who pool their financial resources.

\section{Contending with the Murkiness}

In their relationships, same-sex couples face the same general economic choices as different-sex couples. They may decide to pool their finances completely, to keep their finances completely separate from each other, or to pool certain of their economic resources while keeping others separate. ${ }^{88}$ Yet, despite being faced with the same economic choices, the tax ramifications of these couples' choices depend entirely on their sexual orientation. Different-

\footnotetext{
${ }^{86}$ Infanti, Sodomy Statute, supra note 19, at 788-89.

${ }^{87}$ Patricia A. Cain, Relitigating Seaborn: Taxing the Community Income of California Registered Domestic Partners, 111 TAx Notes (TA) 561, 561-62, 567-68 (2006) [hereinafter Cain, Relitigating Seaborn]; Infanti, Sodomy Statute, supra note 19, at 789; Dennis J. Ventry, Jr., No Income Splitting for Domestic Partners: How the IRS Erred, 110 TAx Notes (TA) 1221, 1221 n.2 (2006) [hereinafter Ventry, Income Splitting]; see also Anthony C. Infanti, Homo Sacer, Homosexual: Some Thoughts on Waging Tax Guerrilla Warfare, 2 Unbound: Harv. J. of THe Legal LEFT 27, 52 n.110 (2006), available at http://www.law.harvard.edu/students/orgs/unbound/ articles/2UNB027-Infanti.pdf [hereinafter Infanti, Homo Sacer] (describing how the Service only issued guidance on the reporting of earned income by same-sex couples registered as domestic partners in California weeks before the end of the tax filing season and issued that guidance in a form that is prohibited by law from being cited as precedent).

The guidance on the tax treatment of the earned income of California registered domestic partners described by Cain in Relitigating Seaborn, Infanti in Homo Sacer, and Ventry in Income Splitting has recently been incorporated into a publication prepared for taxpayers living in community property states. Internal Revenue Serv., Dep't of Treasury, Publ'n No. 555, Community Property 2 (2007). Unfortunately, this guidance is of little real help to California registered domestic partners. Like the Defense of Marriage Act, this guidance actually raises more questions than it answers because it is phrased in the negative: "If you are a registered domestic partner in California, the rules discussed in this publication for reporting community income do not apply to you." Id. Simply telling same-sex couples that they will not be accorded the same tax treatment as married different-sex couples does nothing to tell them what tax rules will apply to their situations and how transactions between the registered domestic partners should be reported for tax purposes. For a list of some of the questions that this guidance leaves unanswered, see Cain, Relitigating Seaborn, supra, at 567-68.

${ }^{88}$ For a discussion of pooling by same-sex couples, see Infanti, Sodomy Statute, supra note 19 , at 784 n.42.
} 
sex married couples can choose whichever arrangement best suits their needs without worrying about the tax ramifications. Regardless of the extent to which they pool their resources, different-sex married couples are treated as a single economic unit for tax purposes and transfers within that unit are, therefore, wholly disregarded ${ }^{89}$ In contrast, same-sex couples who have married or entered into a civil union or domestic partnership are nonetheless treated as two separate, "single" economic units, even if they actually pool all of their economic resources. This means that, far from being disregarded, transactions within a same-sex couple can have serious tax consequences.

Because transactions within a same-sex couple are not disregarded for federal tax purposes, a same-sex couple must annually calculate and document their respective contributions to the economic pool and determine the amount, if any, of the net transfer from the higher-earning partner to the lower-earning partner that results from differing contributions to the pool (the net interspousal transfer). ${ }^{90}$ In practice, this task will be difficult, if not impossible, for same-sex couples to accomplish:

The Code essentially requires these couples to keep records documenting every penny that they spend, save, or give away to third parties. Every trip to the grocery store, the clothing store, and the bank must be documented to determine who spent what and on whom .... Think for a moment of the mountain of shopping receipts that you collect every month. Then think of having to catalogue each of these receipts contemporaneously according to what was spent and on whom. Then think about having to tally up the total at the end of the year. Then think about having to list every one of these transactions on a tax return, showing the particulars of what was given, by whom, and to whom. Finally, think about having to find a place to store this small mountain of paper for six or more years (depending on the relevant tax statute of limitations) in order to provide support for the claimed amount ... of any net interspousal transfer. ${ }^{91}$

Notwithstanding these difficulties, every same-sex couple is required to document the extent of their pooling, even those who do not pool at all. For, without the necessary documentation, the couple will have trouble disproving an assertion by the Service either: (1) that they did, in fact, pool their finances; or (2) in the case of couples who admit to pooling, that the net interspousal transfer was actually larger than claimed by the couple. ${ }^{92}$ This is important

${ }^{89}$ H.R. ReP. No. 98-432, at 1491 (1984), reprinted in 1984 U.S.C.C.A.N. 697, 1134 ("The committee believes that, in general, it is inappropriate to tax transfers between spouses. This policy is already reflected in the Code rule that exempts marital gifts from the gift tax, and reflects the fact that a husband and wife are a single economic unit."); see I.R.C. $\$ \$ 1041$, 2056, 2523.

${ }^{90}$ Because differing contributions to the economic pool will usually be due to differing wage levels, I refer to the partner who contributes more to the pool as the "higher-earning" partner and to the partner who contributes less to the pool as the "lower-earning" partner.

${ }^{91}$ Infanti, Sodomy Statute, supra note 19, at 798 (footnotes omitted).

${ }^{92}$ See id. 
because, in federal tax matters, the burden of proof is placed on the taxpayer (here, the same-sex couple), and the Service benefits from an initial presumption that its own position is correct. ${ }^{93}$

Once a same-sex couple has managed this Sisyphean task, they must then turn to the enigmatic task of characterizing the net interspousal transfer both for income and for gift tax purposes. ${ }^{94}$ For income tax purposes, the amount of the net interspousal transfer may be treated as income to the higher-earning partner and as one of the following in the hands of the lower-earning partner: (1) an excludible gift, (2) an excludible support payment, (3) taxable income, or (4) some combination of the above. ${ }^{95}$ For gift tax purposes, the amount of the net interspousal transfer may be treated as: (1) a taxable gift, (2) "a non-taxable payment made in exchange for rendering domestic services or for furnishing some other consideration in money or money's worth," (3) a nontaxable support payment, or (4) some combination of the above. ${ }^{96}$ It is worth noting that there is no requirement that the net interspousal transfer be treated consistently for income and for gift tax purposes, which only serves to multiply the number of potential characterizations. ${ }^{97}$

Same-sex couples are thus faced with a whole spectrum of possible combinations of characterizations for a single year's net interspousal transfer, with widely varying tax consequences. At one end of this spectrum, we find the most benign characterizations; for example, the same-sex couple might take the position that the net interspousal transfer constitutes a support payment. This is beneficial because the lower-earning partner could exclude the support payment from her gross income and the support payment would not be taxable for gift tax purposes. This would result in, at most, a single layer of tax-in the hands of the higher-earning partner. This benign characterization is roughly equivalent to the treatment that is afforded to different-sex married couples, for whom net interspousal transfers are essentially disregarded.$^{98}$ At the other end of the spectrum, we find the most punitive of characterizations; for example, the Service might assert that the net interspousal transfer should "be characterized as income to both partners for income tax purposes and as a taxable gift from the higher-earning partner to the lower-earning partner for gift tax purposes. Consequently, a portion of the income of the higher-earning partner might be subject to triple taxation." ${ }^{99}$ In between these

\footnotetext{
${ }^{93}$ See id. at 790.

${ }^{94} \mathrm{Id}$. at $784-85$.

${ }^{95} \mathrm{Id}$. at 785 .

${ }^{96} \mathrm{Id}$. at $785-86$.

${ }^{97}$ See id. at 787.

${ }^{98}$ See, e.g., I.R.C. $\$ \$ 1041,2056,2523$. I say roughly equivalent because of the differing tax rates that apply to married couples and singles. See I.R.C. $\$ 1$.

${ }^{99}$ Infanti, Sodomy Statute, supra note 19, at 788.
} 
two ends of the spectrum are combinations of characterizations that might be considered merely malignant, because they involve some form of double (rather than triple) taxation of the couple; for example, the net interspousal transfer might be considered income to both the higher- and lower-earning partners for income tax purposes but as a nontaxable payment for services for gift tax purposes.

Despite this dizzying (not to mention frightening) array of possibilities, neither Congress nor the Service has provided same-sex couples with guidance on how to characterize net interspousal transfers for federal tax purposes. ${ }^{100}$ Coming, as it does, in the face of decades of discussion by commentators concerning the uncertain tax treatment of same-sex couples, this silence is deafening. ${ }^{101}$ What makes this silence even more troubling is that, once again, "the tax laws place the burden on gay and lesbian couples to prove that their chosen treatment is correct ... [and further] attach a presumption of correctness to whatever treatment the [Service] deems appropriate-after the fact and without any advance public notice." ${ }^{102}$ Even so, those same-sex couples who, in retrospect, erred in choosing the "correct" tax treatment for their net interspousal transfers can find themselves subject to civil or criminal penalties (or both), on top of any additional tax and interest that they might owe. ${ }^{103}$

When the federal government's silence is coupled in this way with the specter of confiscatory levels of taxation along with civil or criminal penalties (or both), the Code begins to take on the appearance of a sodomy statute. It doles out potentially harsh punishment for lesbians and gay men who dare to couple, and it creates a clear incentive for lesbians and gay men to retreat to the "safety" 104 of the closet-by filing returns with the Service that avoid at all costs making any connection between one partner in a same-sex couple and the other. ${ }^{105}$

\section{Contending with So-Called Guidance}

In the rare instance when the federal government does speak, it is not necessarily to illuminate the "correct" answer for same-sex couples. A telling example is found in recent guidance on the federal tax treatment of same-sex couples who are registered as domestic partners in California. Beginning on January

${ }^{100} I d$. at 789 .

${ }^{101}$ See, e.g., Cain, Heterosexual Privilege, supra note 85, at 493; see also id. at 491-94; Patricia A. Cain, Same-Sex Couples and the Federal Tax Laws, 1 Tul. J.L. \& Sexuality 97 (1991); Patricia A. Cain, Taxing Lesbians, 6 S. Cal. Rev. L. \& Women's Stud. 471, 475-79 (1997); Adam Chase, Tax Planning for Same-Sex Couples, 72 Denv. U. L. Rev. 359, 373-93 (1995); Infanti, Sodomy Statute, supra note 19, at 783-804; Knauer, supra note 24, at 165-84; Bruce Wolk, Federal Tax Consequences of Wealth Transfers Between Unmarried Cohabitants, 27 UCLA

L. Rev. 1240 passim (1980).

${ }^{102}$ Infanti, Sodomy Statute, supra note 19, at 790.

${ }^{103} I d$. at $790-800$.

${ }^{104}$ See id. at 771 (describing how the closet is far from being a "safe" place).

${ }^{105}$ Id. at $800-03$. 
1, 2005, domestic partners began to be subject to that state's community property laws, which accord each partner a one-half interest in all property acquired during the domestic partnership while domiciled in California. ${ }^{106}$ The extension of the community property laws to domestic partners naturally raised the question whether the Service would allow domestic partners to split their earned income for federal tax purposes, as do married differentsex couples subject to California's community property laws. ${ }^{107}$

An answer to this question was sought some seventeen months before registered domestic partners would have had to file their first federal income tax returns with respect to a taxable year in which they would be covered by California's community property laws. In November 2004, attorney Donald Read, with the assistance of tax professor Pat Cain, prepared and submitted a proposed Revenue Ruling on the question to the Treasury Department for its consideration. ${ }^{108}$ The proposed Revenue Ruling adopted the incomesplitting approach in reliance on the longstanding Supreme Court precedent of Poe v. Seaborn. ${ }^{109}$ In that decision, which hinged on the spouses' property rights under state law (and not on their marital status as such), the Court held that, because each spouse owns one-half of the other's earned income under state law, the earned income of the community must be split equally between the spouses for federal income tax purposes. ${ }^{110}$ Despite the pressing need for public guidance on this issue, the Treasury Department and the Service remained silent for more than fifteen months after receiving Read and Cain's submission. ${ }^{111}$

Finally, on February 24, 2006, the Service spoke, but "[i]t spoke in a whisper." 112 On that date, the Chief Counsel's Office issued a memorandum in which it opined that California registered domestic partners must each report their earned income separately because, it claimed, Poe v. Seaborn applies only to married couples. ${ }^{113}$ This opinion came late-only a few short weeks before the April 15 deadline for filing the first federal income tax returns with respect to a taxable year in which domestic partners were covered by California's community property laws. Yet, "[f] or some undisclosed reason, the memorandum was not made public along with other IRS announcements released that Friday, but instead was released the following Monday, February

${ }^{106}$ CAL. FAM. Code $\$ \$ 297.5(a),(k), 751,760$ (West 2007).

${ }^{107}$ See United States v. Malcolm, 282 U.S. 792 (1931) (per curiam).

${ }^{108}$ Donald H. Read, Attorney Offers Draft Revenue Ruling Affecting Domestic Partners (2004), available at LEXIS, 2004 TNT 227-31.

${ }^{109} 282$ U.S. 101 (1930).

${ }^{110} I d$. at 118 .

${ }^{111}$ Cain, Relitigating Seaborn, supra note 87, at 562.

${ }^{112} I d$.

${ }^{113}$ G.C.M. 2006-08-038 (Feb. 24, 2006), available at http://www.irs.gov/pub/irs-wd/ 0608038.pdf. 
27." ${ }^{114}$ Commentators roundly criticized this "guidance" 115 for being "unpersuasive, historically inaccurate, and ultimately indefensible." ${ }^{116}$ They pointed out that, as mentioned above, Poe v. Seaborn "had everything to do with the principle of ownership under community property law and very little to do with marriage." 117 Indeed, "marriage, per se, had nothing to do with the Supreme Court's family tax jurisprudence in the 1920s and 1930s." 118 At the time,

the Court was exclusively concerned with principles of ownership on one hand, and management and control on the other. In fact, "marriage" informed the Court's analysis only to the extent that rights and obligations under community property law-as well as any attendant tax advantages - were reserved for married couples in $1930 .{ }^{119}$

Given this harsh criticism and the fact that the Chief Counsel's Office makes an error of interpretation that no decent second-year law student should make, ${ }^{120}$ one can only surmise that this guidance was driven more by ideology than by objective legal analysis aimed at ascertaining the correct applica-

\footnotetext{
${ }^{114}$ Cain, Relitigating Seaborn, supra note 87 , at 562 . As mentioned above, this guidance was recently incorporated in a publication prepared by the Service for taxpayers in community property states. See supra note 87.

${ }^{115} \mathrm{I}$ am not really sure that you can truly call something "guidance" when it is issued in a form that is prohibited by law from being cited as precedent. I.R.C. $\$ 6110(\mathrm{k})(3)$; see also G.C.M. 2006-08-038 (Feb. 24, 2006) ("In accordance with $\$ 6110(\mathrm{k})(3)$ this advice may not be used or cited as precedent.").

${ }^{116}$ Ventry, Income Splitting, supra note 87, at 1221; see Cain, Relitigating Seaborn, supra note 87 , at $566-67$.

${ }^{117}$ Ventry, Income Splitting, supra note 87, at 1224; see Cain, Relitigating Seaborn, supra note 87 , at 567.

${ }^{118}$ Ventry, Income Splitting, supra note 87, at 1224.

${ }^{119}$ Id.; see Cain, Relitigating Seaborn, supra note 87, at 567.

${ }^{120}$ Cain, Relitigating Seaborn, supra note 87, at 567.
}

To support [its] conclusion the IRS cites one fact: "The case law relating to incomesplitting in community property states has always arisen solely in the context of spouses."

$\cdots$

... Regarding the cited fact, it is both irrelevant and wrong. If limited to the question whether community income can be split because of the state community property law rules, then, yes, of course, that specific question has arisen only in cases involving spouses. That is because before 2005 no state had ever extended community property rights to anyone other than spouses. That reasoning is similar to an example I often use with first-year law students to help them understand the ratio decidendi of a case. Just because the first three tort liability cases in a jurisdiction find the driver of a red automobile negligent does not mean that the negligence rule is limited to the drivers of red cars. The color of the car is irrelevant. Similarly, the spousal status in Seaborn is irrelevant. It is the vested nature of the right that is given to the spouses by the state law that is the ratio decidendi of the case. 
tion of the tax laws to the earned income of California registered domestic partners. ${ }^{121}$

\section{Contending with Impossible Burdens}

In its interactions with lesbian and gay taxpayers, the Service has also taken advantage of the nearly impossible burden placed on same-sex couples to document whether, and if so, to what extent, they pool their finances. Pat Cain provides evidence of this behavior in a series of narratives included in a piece that she contributed to a symposium on the estate tax. ${ }^{122}$ Cain obtained these narratives "from lawyers and accountants who have represented gay and lesbian clients in estate tax audits." 123 To maintain confidentiality, she "either elaborated on or amalgamated the specific facts from individual cases." ${ }^{124}$ The two narratives that are directly relevant to the instant discussion are short enough to reproduce in full:

Alice and Barb are a lesbian couple in Ohio. They had lived together for over forty years when Alice died. The auditing agent took the position that since Alice was the wealthy partner, everything she paid for over the forty years that benefited Barb was an adjustable [sic] taxable gift. Thus, Alice's ownership of the couple's residence which was used by Barb created an adjusted taxable gift. Vacation trips for the two of them paid out of Alice's funds created an adjusted taxable gift. Entertainment

${ }^{121}$ In discussing the errors in the Service's analysis, Ventry observes that:

[T] he IRS's analysis suggests that ownership of domestic partnership income ends up in one or the other partner not by operation of law, but under some other (as yet, unexplained) theory. By gift? By contract? It is impossible to tell from the memorandum. I suspect the sleight of hand derives from the awareness that if the IRS acknowledged ownership interests for domestic partners on a par with married couples under California community property law, it would have to treat—and taxthe two groups the same.

Ventry, Income Splitting, supra note 87, at 1225.

It is worth noting that this is not the only area in which the Bush administration has resisted enforcing laws that benefit lesbians and gay men. For example, the Bush administration has been less than enthusiastic about enforcing employment discrimination protections afforded to lesbian and gay federal employees and, through executive order, has actually ended the unequivocal prohibition of discrimination on the basis of sexual orientation in the granting of security clearances that the Clinton Administration had put in place. See Christopher Lee, Groups Applaud Discrimination Ban, WASH. Post, Apr. 10, 2004, at A3 (discussing the administration's resistance to enforcing prohibitions against discrimination on the basis of sexual orientation for federal employees). Compare Memorandum from Stephen J. Hadley, Assistant to the President for Nat'l Sec. Affairs, Adjudicative Guidelines for Determining Eligibility for Access to Classified Info., to William Leonard, Dir. Info. Sec. Oversight Office, Guideline D: Sexual Behavior 12 (Dec. 29, 2005), available at http://www.fas.org/sgp/isoo/guidelines. html, with Exec. Order No. 12,968, \$3.1(c)-(d), 60 Fed. Reg. 40,245, 40, 250 (Aug. 2, 1995). For further discussion, see Anthony C. Infanti, Everyday Law for Gays and Lesbians (and Those Who Care About Them), at ch. 5 (2007).

${ }^{122}$ Patricia A. Cain, Death Taxes: A Critique from the Margin, 48 Clev. St. L. Rev. 677, 696-97 (2000) [hereinafter Cain, Death Taxes].

${ }^{123} \mathrm{Id}$. at 696.

${ }^{124} I d$. 
expenses and meals at fancy restaurants - all items of joint consumption-were proposed as adjusted taxable gifts. Although the case was finally settled, the audit lasted over two years.

Carl and Dan are a gay male couple in California. They owned all their property as joint tenants and considered it "community property." 125 The property included real estate and joint checking accounts and a joint CD. They purchased some of the property twenty years ago. Carl was earning slightly more than Dan at the time of Carl's death. The agent asked for proof of Dan's original contribution to every piece of joint property. Dan had not retained cancelled checks for twenty years, but he did have tax returns. He was able to show that he made enough money to enable him to cover half the down the [sic] payment for the property purchased twenty years ago. On the more recent purchases, Dan was eventually able to produce cancelled checks to account for $40 \%$ of the funds needed for the down payment. Data on the bank accounts varied. The agent asked for proof of equal contribution to the mortgage payments. Dan had no cancelled checks to the mortgage company, but was able to show some cancelled checks to Carl which appeared to be partial reimbursements. They had split the interest deduction and property tax deduction equally on their tax returns over the years. Again the case was ultimately settled, but the taxpayer's representative who shared this story with me says she will never allow a gay or lesbian client to own property jointly. Even if they can substantiate contributions, the emotional toll is not worth the benefit of avoiding probate or reaping the benefits of Proposition 13, which is also an issue for nonspousal property owners in California. ${ }^{126}$

The stories of Alice and Barb and Carl and Dan, illustrate the ways in which the Service uses its hefty procedural advantages - that is: (1) the impossible recordkeeping burden imposed on same-sex couples, (2) the couples' resulting difficulties in carrying the burden of going forward with evidence (that is, rebutting the presumption of correctness that attaches to the Service's determination), and (3) the couples' further difficulties in ultimately carrying the burden of proof that is placed on them ${ }^{127}$ - to the detriment of lesbian and gay taxpayers.

\section{Summarizing Our Predicament}

The relationship between lesbian and gay taxpayers and the Service looks nothing like the (now, clearly) heteronormative view of the taxpayer-Service relationship that underpins the conventional conceptualization of the duty to the tax system. Far from finding themselves in a presumptively cooperative relationship, lesbian and gay taxpayers must contend with a federal gov-

\footnotetext{
${ }^{125}$ Please note that this narrative pre-dates the creation of the California domestic partnership registry. 1999 Cal. Legis. Serv. ch. 588 (West). As discussed earlier, California actually extended its community property laws to cover registered domestic partnerships. See supra note 105 and accompanying text.

${ }^{126}$ Cain, Death Taxes, supra note 122, at 696 (footnote omitted).

${ }^{127}$ For a discussion of the difference between the presumption of correctness or burden of going forward with evidence and the burden of proof, see Michael I. SaltzMan, IRS PracTice ANd Procedure g9 1.05[2][b], 7B.11[2][a] (2d ed. Supp. 2002).
} 
ernment that has already declared itself openly hostile to them. The federal government has enacted legislation that overtly discriminates against samesex couples; has generally refused to provide guidance on the tax treatment of same-sex couples in areas left unclear by that legislation; has provided unsound, ideologically-motivated guidance when it has spoken; and has used its tactical advantages to persecute lesbian and gay taxpayers. In addition, far from having the upper hand in this relationship, lesbian and gay taxpayers find themselves constantly on the defensive. Furthermore, their only protection from an empowered and overreaching federal government is not really a form of protection at all, but just additional punishment: Lesbians and gay men can most effectively counteract the Service's advantages by retreating into the closet; that is, by effacing all references to their relationship from their tax returns and playing the audit lottery. ${ }^{128}$ As a result, what heterosexual taxpayers experience as a distinct tactical advantage in their dealings with the Service, lesbian and gay taxpayers experience as a self-inflicted form of punishment that merely substitutes for a more humiliating, publicly-inflicted punishment. ${ }^{129}$

Now, just imagine what would happen if a tax lawyer who scrupulously fulfills her duty to the tax system when representing conventional (that is, heterosexual) taxpayers were to decide that she must do likewise in her representation of lesbian and gay taxpayers. In all likelihood, this tax lawyer would quickly encounter the conflicting pull between her duty to the tax system and her duty of zealous advocacy, if only because the woefully inadequate level of guidance from Congress and the Service on the tax treatment of same-sex couples causes so many transactions entered into by these couples to fall into the "gray zone." To resolve doubts in favor of the Service in this enlarged gray area-doubts that, by the way, the Service has itself deliberately helped to create-would risk doing serious harm to the tax lawyer's lesbian and gay clients. In this regard, let us return to the example of characterizing a same-sex couple's net interspousal transfer. On any scale of "questionable" positions, the least questionable (and, from the perspective of strictly applying the conventional conceptualization of the duty to the tax system, the most acceptable) positions will tend to be those involving at least double, if not triple, taxation of a same-sex couple's income. On this same scale, the most questionable positions will tend to be those involving any characterization that results in a single level of taxation and, therefore, places the same-sex couple's tax treatment on a par with that of a different-sex married couple. In this context, resolving doubts in favor of the Service makes the tax lawyer nothing less than an accessory to invidious discrimination. Moreover, the possibility that the conventional conceptualization of the duty to the tax system might

\footnotetext{
${ }^{128}$ See Infanti, Sodomy Statute, supra note 19, at 803.

${ }^{129}$ See supra note 104 and accompanying text.
} 
shape the tax lawyer's advice entirely sub rosa-in other words, without the lesbian or gay client even knowing that her lawyer has put a thumb firmly on the Service's side of the scale-only makes the conventional conceptualization that much more insidious.

\section{Seeing the Duty to the Tax System in a Different Light}

Given this predicament, the question then becomes whether the duty to the tax system has any role to play in a tax lawyer's representation of her lesbian and gay clients. I believe that it does, but only if we eschew unthinking application of the conventional conceptualization of the duty to the tax system in favor of a critical reconstruction of it. To this end, this Part deconstructs the conventional conceptualization of the duty to the tax system in an effort to open the necessary ethical space for crafting an alternative view of that duty-one that better suits the representation of lesbian and gay clients than does the conventional conceptualization.

\section{A. Deconstructing the Duty to the Tax System}

In discussions of the duty to the tax system, as in discussions of a lawyer's general duties to the legal system, ${ }^{130}$ commentators often speak of the duty as being necessary to maintain the "integrity" of the tax system. ${ }^{131}$ This link between the duty to the tax system and the system's perceived integrity is both interesting and quite revealing. To understand why, we will need first briefly to look at the meaning and origin of the word "integrity" and then consider whether the current treatment of lesbians and gay men under the tax laws contributes to - or, conversely, erodes - the integrity of our tax system.

In its entry for the word "integrity," the Oxford English Dictionary (OED) includes two different senses of the word: a general sense and a moral sense. The OED generally defines "integrity" as "[t] he condition of having no part or element taken away or wanting; undivided or unbroken state; material wholeness, completeness, entirety." 132 In a similar (yet alternative) formulation, it defines "integrity" as "[t] he condition of not being marred or violated; unimpaired or uncorrupted condition; original perfect state; soundness." ${ }^{133}$ Following these entries for the general definition of "integrity," the $O E D$ includes the moral sense of the word, which it defines as "[s] oundness of moral principle; the character of uncorrupted virtue, esp. in relation to truth and fair dealing; uprightness, honesty, sincerity." ${ }^{134}$ The $O E D$ further indicates

\footnotetext{
${ }^{130}$ See supra text accompanying note 12.

${ }^{131}$ See, e.g., Beale, supra note 1, at 601, 609, 661; Infanti, Eyes Wide Shut, supra note 19, at 609-10; Lavoie, Gunslingers, supra note 14, at 78 n.97, 79; Thrower, supra note 14; Ames, supra note 14, at 413; Southworth, supra note 14, at 891, 909.

${ }^{132} 1$ Oxford English Dictionary 1455 (Compact ed. 1971).

${ }^{133} I d$.

${ }^{134} I d$.
} 
that the word "integrity" can be traced back to the Latin "integritās," which connotes "wholeness, entireness, completeness, integrity, chastity, purity." 135

In keeping with this Latin origin that intertwines both the general and the moral senses of the word, commentators seem to employ these two senses in tandem when they speak of the "integrity" of the tax system. Drawing first upon the moral sense of "integrity," commentators worry that tax lawyers' facilitation of overly aggressive behavior on the part of taxpayers will undermine public confidence in the fair, honest, and upright application of the tax laws. Then drawing upon the general sense of "integrity," commentators posit that, failing this public confidence, aggressive behavior can only be expected to spread and, eventually, to undermine the soundness of the tax system by impairing its ability to collect the revenue that is necessary for the government to function. Notwithstanding their use of both senses of the word in these discussions, commentators plainly privilege the moral sense of the word "integrity" by treating the absence of public confidence in the fair, honest, and upright application of the tax laws as the predicate for their worries about the potential impairment of the tax system's soundness (that is, its "integrity" in the general sense). ${ }^{136}$

Acknowledging the importance of the moral dimension of the "integrity" of the tax system, let us now reflect on whether the application of the tax laws to lesbians and gay men contributes to-or, conversely, erodes- the perception of our tax system as fair, honest, and upright. Based on the extended discussion in Part III above, I trust that you will agree that targeting lesbians and gay men for explicitly inferior treatment, setting them adrift on a sea of potential tax characterizations for routine transactions (and, when providing them some direction, doing so in a way that advances ideology rather than the "correct" application of the tax laws), and using hefty tactical advantages to selectively persecute lesbians and gay men is, if anything, the antithesis of the fair, honest, and upright application of the tax laws. Moreover, if "what counts as justice in taxation cannot be determined without considering how government allocates its resources," ${ }^{137}$ then the picture only becomes more disturbing when we look at what the federal government does with the tax dollars that it extorts from lesbians and gay men. ${ }^{138}$ The federal government uses those dollars to: (1) deny legal recognition to same-sex relationships for all purposes of federal law (and not just tax purposes) under the so-called

${ }^{135} I d$.

${ }^{136}$ Cf. Susan Pace Hamill, An Evaluation of Federal Tax Policy Based on Judeo-Christian Ethics, 25 VA. TAX REv. 671, 747 (2006) ("[T]ax policy is one of the most telling indicators of the nation's true moral compass ....").

${ }^{137}$ Liam Murphy \& Thomas Nagel, The Myth of Ownership: Taxes and Justice 14 (2002).

${ }^{138}$ The list of examples that follows in the text above is adapted from Infanti, Tax Equity, supra note 22 , at $1253-54$. 
Defense of Marriage Act — an injunction that has been taken so far as to deny a lesbian U.S. citizen a passport because her application listed not her maiden name, but her name as changed on her marriage license when she married her partner in Massachusetts; ${ }^{139}$ (2) require those whose same-sex relationships are legally recognized under state law to incur unnecessary legal and other expenses in an effort to replicate that legal recognition in a way that will be recognized by other states, again because of the Defense of Marriage Act; ${ }^{140}$ (3) until 2002, prevent the District of Columbia from implementing the domestic partnership regime that it had enacted in $1992 ;^{141}$ (4) amend the District of Columbia's Human Rights Act to allow Georgetown University to refuse to recognize lesbian and gay student groups despite a court ruling to the contrary; ${ }^{142}(5)$ actively engage in employment discrimination against lesbians and gay men through its "Don't Ask, Don't Tell" policy; ${ }^{143}$ and (6) provide rather precarious protections against discrimination on the basis of sexual orientation to its other employees. ${ }^{144}$ Thus, far from contributing to the fair, honest, and upright application of our tax laws, the federal government actively erodes the integrity of the tax system by using the tax laws to engage in invidious discrimination against lesbians and gay men.

It is well established in American society that neither individuals nor the government should engage in such invidious discrimination. With respect to the government, the abnegation of invidious discrimination is most clearly and directly expressed in the Equal Protection Clause of the U.S. Constitution, which guarantees all persons "the equal protection of the laws" and which has been construed by the courts to bind all levels of our government. ${ }^{145}$ This abnegation is rooted in the Golden Rule (that is, "do unto others as you would have them do unto you"), ${ }^{146}$ which most individuals aspire

${ }^{139} 1$ U.S.C. $\$ 7$ (2007); Dianne Williamson, Gay Right Springs a Leak, Worcester Tel. \& GaZETTE, Mar. 4, 2007, at B1. For further discussion, see Infanti, supra note 121, at ch. 6.

${ }^{140} 28$ U.S.C. $\$ 1738 \mathrm{C}$ (2007). For further discussion, see InfantI, supra note 121, at chs. 6-8.

${ }^{141}$ Compare District of Columbia Appropriations Act of 2002, Pub. L. No. 107-96, 115 Stat. 923, 950 (2001), with District of Columbia Appropriations Act of 1993, Pub. L. No. 102-382, 106 Stat. 1422, 1422 (1992).

${ }^{142}$ District of Columbia Appropriations Act of 1990, Pub. L. No. 101-168, $\$ 141,103$ Stat. 1267, 1284 (1989) (codified at D.C. Code $\$ 2-1402.41(3)(2007)$ ).

${ }^{143} 10$ U.S.C. $\$ 654$ (2007). For further discussion, see Infanti, supra note 121, at ch. 4.

${ }^{144}$ See supra note 121.

${ }^{145}$ U.S. Const. amend. XIV, $\$ 1$. ("No State shall . . . deny to any person within its jurisdiction the equal protection of the laws."); see Bolling v. Sharpe, 347 U.S. 497, 500 (1954) (holding that the guarantee of equal protection applies to the federal government as well); Buckley v. Valeo, 424 U.S. 1, 93 (1976) (same).

${ }^{146}$ See Cruzan v. Dir., Mo. Dep't of Health, 497 U.S. 261, 300 (1990) (Scalia, J., concurring) ("Our salvation is the Equal Protection Clause, which requires the democratic majority to accept for themselves and their loved ones what they impose on you and me."). 
to follow in their daily lives ${ }^{147}$ and which forms a part of religious traditions from around the world, including Buddhism, ${ }^{148}$ Christianity, ${ }^{149}$ Confucianism, ${ }^{150}$ Hinduism, ${ }^{151}$ Islam,,${ }^{152}$ and Judaism. ${ }^{153}$ The abnegation of invidious discrimination can even be detected in various strains of philosophy, including Aristotle's statement that "we should behave to our friends 'as we should wish them to behave to us" "154 and Immanuel Kant's categorical imperative: "Act only according to that maxim by which you can at the same time will that it should become a universal law."155

With moral dictates set firmly against the federal government's treatment of its lesbian and gay taxpayers, the duty to the tax system begins to take on an entirely different cast. It should by now be clear that the conventional conceptualization of the duty to the tax system harms not only lesbians and gay men but also the tax system itself. As discussed earlier, a tax lawyer who adheres to the conventional conceptualization of the duty to the tax system in the representation of lesbian and gay clients may harm her clients by facilitating the federal government's immoral (if not illegal) invidious discrimination against them. ${ }^{156}$ At the same time, by dint of her role as accessory to this dis-

\footnotetext{
${ }^{147}$ Indeed, Jonathan Haidt, a moral psychologist at the University of Virginia, ascribes the ubiquity of this moral rule to the evolutionary process, because the Golden Rule and other moral limits on selfishness make it possible for humans to live in groups. See Nicholas Wade, Is "Do unto Others" Written into Our Genes?, N.Y. Times, Sept. 18, 2007, at D1.

${ }^{148}$ The Udāna: Sacred Books of the Buddhists 87-88 (Peter Masefield trans., Oxford: Pali Text Society 1994) ("Having explored all quarters with the mind, one would simply not attain that dearer than the self in any place; thus is the self dear separately to others-therefore one desiring self should not harm another.").

${ }^{149}$ Luke 6:31 (King James) ("And as ye would that men should do to you, do ye also to them likewise."); id. 10:27 ("And he answering said, Thou shalt love the Lord thy God with all thy heart, and with all thy soul, and with all thy strength, and with all thy mind; and thy neighbor as thyself."); Matthew 7:12 (King James) ("Therefore all things whatsoever ye would that men should do to you, do ye even so to them: for this is the law and the prophets."); id. 22:39 ("And the second is like unto it, Thou shalt love thy neighbor as thyself.").

${ }^{150}$ Confucius, The Analects 176 (David Hinton trans., Counterpoint 1998) (“Adept Kung asked: 'Is there any one word that could guide a person through-out life?' The Master replied: 'How about 'shu': never impose on others what you would not choose for yourself?").

${ }^{151} 11$ The Mahabharata of Krishna-Dwaipayana Vyasa $\$$ CXIII, at 240 (Pratap Chandra Roy trans., Oriental Publ'g. Co. 1962) ("One should never do that to another which one regards as injurious to one's own self. This, in brief, is the rule of Righteousness.").

${ }^{152}$ Muhammad Husayn Haykal, The Life of Muhammad 486 (Isma'il Ragi A. al Faruqi trans., N. Am. Trust Publ'ns 8th ed. 1976) ("You will neither inflict nor suffer inequity.").

${ }^{153}$ Leviticus 19:18 (King James) ("Thou shalt not avenge, nor bear any grudge against the children of thy people, but thou shalt love thy neighbour as thyself: I am the LORD.").

${ }^{154} \mathrm{John}$ A. Miller, Rationalizing Injustice: The Supreme Court and the Property Tax, 22 Hofstra L. Rev. 79, 133 n.202 (1993) (quoting Diogenes Laertius, Lives of Eminent Philosophers, bk. V, $\$ 21$ (R.D. Hicks trans., Harvard Univ. Press 1950)).

${ }^{155}$ Immanuel Kant, Foundations of the Metaphysics of Morals 44 (Lewis White Beck trans., Bobbs-Merrill Educ. Publ'g 1969) (1785).

${ }^{156}$ See supra Part III.C.
} 
criminatory treatment, the tax lawyer acts contrary to the interests of the tax system itself, eroding the very integrity that discharging her duty to the tax system is supposed to protect and preserve.

The dual harm (that is, to the client and to the tax system) wreaked by the reflexive application of the conventional conceptualization of the duty to the tax system reveals the possibility that there may be more of an alignment than an opposition of a tax lawyer's client-regarding and public-regarding duties in the context of representing lesbian and gay taxpayers. In this context, it becomes possible to imagine an alternative conceptualization of the duty to the tax system-one which exists in harmony with, rather than in opposition to, the duty of zealous advocacy. This alternative view, which I develop further in the next section, would allow a tax lawyer simultaneously to protect her lesbian and gay clients from harm and to discharge her obligation to safeguard the integrity of the tax system, all by actively preventing abuse by an overreaching federal government.

\section{B. Reconstructing the Duty to the Tax System}

The first step toward reconceptualizing the duty to the tax system in this way involves revisiting the description of the contours of that duty in Part II.B. One of the first things that I noted there about the duty to the tax system is its ambiguity. The duty to the tax system clearly means different things to different people. For many, it directly affects the advice that a tax lawyer provides to her clients. For others, however, it does not directly affect the attorney-client relationship, but merely requires the tax lawyer, as a citizen, to use her training to work toward the improvement of the tax system. Even for those who subscribe to the view that the duty to the tax system can directly impact the attorney-client relationship, it is difficult to define precisely when or how the duty to the tax system ought to be privileged over the duty of zealous advocacy. ${ }^{157}$ Consequently, if one thing is clear about the duty to the tax system, it is that the contours of that duty are far from unyielding. Given the tractability of the duty to the tax system, there is no good reason why we cannot carefully reshape the contours and content of that duty to fit more closely the needs of tax lawyers representing lesbian and gay clients. ${ }^{158}$

\footnotetext{
${ }^{157}$ See supra Part II.B.

${ }^{158}$ It is worth underscoring here that this discussion does not strictly concern the question whether tax lawyers have a duty to obey the law; thus, for example, I am not arguing that tax lawyers should advise same-sex couples to file joint federal income tax returns-in clear contravention of DOMA - if they would benefit from the marriage bonus. Nevertheless, it is possible that a tax lawyer's interpretation of how the tax laws apply to her lesbian and gay clients - when coupled with reliance on the audit lottery to avoid detection-might, in certain situations, amount to a justifiable nullification of the tax laws. See William H. Simon, Should Lawyers Obey the Law?, 38 WM. \& MARY L. Rev. 217, 250-51 (1996); see generally David Luban, Legal Ideals and Moral Obligations: A Comment on Simon, 38 WM. \& Mary L. Rev. 255 (1996); W. Bradley Wendel, Civil Obedience, 104 Colum. L. Rev. 363 (2004); David B. Wilkins, In Defense of Law and Morality: Why Lawyers Should Have a Prima Facie Duty to Obey the Law, 38 WM. \& Mary L. Rev. 269 (1996).
} 
Having recognized that the duty to the tax system is malleable, we must next decide how we will reshape the contours of that duty to make it more closely fit our present needs. In this endeavor, we should avoid the trap of formalism - an error that, ironically, the duty to the tax system is thought to help remedy, especially in the area of tax shelters. ${ }^{159}$ What I mean to say is that we should not conceive of the duty to the tax system as narrowly running to the Service-the party whose lack of information and resources is normally used to justify the imposition of the duty and whom we usually consider to be the obligee of the duty. Otherwise, we would find ourselves reshaping the duty to the tax system for the benefit of the party who, in this context, is actively working to undermine the integrity of the tax system. Instead, we should recall the words of those commentators who remind us that the duty is not owed to a particular government agency or to some disembodied "system," but to all "citizens who ascribe value to a well-functioning tax system." 160 By avoiding the trap of formalism, we can more appropriately focus our efforts on reshaping the duty to the tax system in a way that restores the system's integrity-and, correlatively, returns it to proper functioning order-for the benefit of all of us, both gay and straight.

To begin the process of restoring the integrity of the tax system for the benefit of all of us will require tax lawyers to counter the federal government's use of the tax laws as a tool for invidious discrimination against lesbians and gay men. In other words, a tax lawyer who truly wishes to strive for the fair, honest, and upright application of the tax laws will refuse to be made an accomplice to the government's invidious discrimination against her lesbian and gay clients. In the many areas where the law is unclear, she will resolve any and all doubts in favor of her clients, adopting whatever tax characterization does her clients the least harm possible, and she will encourage her clients to take full advantage of the audit lottery in doing so. She will help her clients to challenge the constitutionality of the government's discriminatory application of the tax laws as well as the soundness of ideologically driven misinterpretations of those laws. She will use every procedural device and failing of the system to her clients' advantage in an effort to prevent the Service from profiting from its own tactical advantages vis-à-vis lesbian and gay taxpayers. In short, to discharge her duty to the tax system and contribute to restoring the integrity of that system, the tax lawyer will treat the Service as a real adversary at every stage of representation (that is, from early tax planning to return preparation to audit and finally on to litigation), and, accordingly, she will zealously advocate on behalf of her lesbian and gay clients from the start to the finish of the representation. ${ }^{161}$

${ }^{159}$ E.g., Lavoie, Gunslingers, supra note 14 , at 79.

${ }^{160}$ Southworth, supra note 14 , at 912.

${ }^{161}$ See Carle, supra note 40, at 139 ("[L]awyers for clients with substantially less power-in other words, lawyers representing 'underdogs' vis a vis powerful interests—-should be guided by the ethical principle of zealous, client-centered representation."). 
To fulfill her public responsibility as a citizen with special knowledge, ${ }^{162}$ the tax lawyer can also lobby for the passage of, as well as educate others about, proposed legislation that is designed to eliminate or, at the very least, to mitigate the discrimination against lesbians and gay men that is currently embedded in our tax laws. ${ }^{163}$ In some cases, however, a tax lawyer may eschew such traditional approaches to battling the imbricated pattern of discrimination in our tax laws in favor of more "radical" strategies for effecting change. For example, I have argued elsewhere ${ }^{164}$ that same-sex couples who have registered as domestic partners in California or who have married in Massachusetts should adopt guerrilla warfare tactics when challenging the application of the tax laws to them (that is, the alleged inapplicability of Poe v. Seaborn to California domestic partners ${ }^{165}$ and the constitutionality of the application of DOMA to Massachusetts same-sex marriages ${ }^{166}$ ). Rather than pursuing a traditional test case strategy, all of the thousands of registered domestic partners and same-sex married couples could file simultaneous challenges that would likely cause a significant-albeit temporary-disruption of the Service's activities. Having captured public attention for their cause, "lesbians and gay men could then begin to educate the masses concerning their tax grievances." 167

It is worth noting the interesting convergences that result from this reshaping of the duty to the tax system. Most notably, there is a convergence here of individual and public interest. The conventional conceptualization of the duty to the tax system is built on the opposition between the individual taxpayer's interest in paying as little tax as possible and the public interest in a smoothly functioning tax system that provides all of the revenue that the government needs and expects to raise. To the contrary, our alternative conceptualization of the duty to the tax system is built on the correlation between the treatment of individual lesbian and gay taxpayers and the soundness of the tax system. Put differently, what helps the individual lesbian or gay taxpayer likewise helps to restore the integrity of our shared tax system. There is also a related convergence here of the duty of zealous advocacy and the duty to the tax system. In the conventional conceptualization of the duty to the tax system, there is a natural tension between the lawyer's duty of zealous advocacy on behalf of her client and her duty to the tax system, with the two duties pulling the lawyer in different directions. But, being based on a correlation between

${ }^{162}$ See supra Part II.B.2.

${ }^{163}$ See, e.g., Tax Equity for Health Plan Beneficiaries Act of 2007, H.R. 1820, 110th Cong. (2007); Tax Equity for Domestic Partner and Health Plan Beneficiaries Act, S. 1556, 110th Cong. (2007).

${ }^{164}$ Infanti, Homo Sacer, supra note 87, at 49-56.

${ }^{165}$ See supra Part III.B.2.b.

${ }^{166}$ See supra Part III.B.1.

${ }^{167}$ Infanti, Homo Sacer, supra note 87, at 56. 
individual and public interest, our alternative conceptualization of the duty to the tax system erases this tension between the duty of zealous advocacy and the duty to the tax system and tends to fuse the two into a single harmonious whole.

Before I conclude, I note that this reshaping of the duty to the tax system is consistent with a general observation that I made about the justification for imposing this duty on tax lawyers. As I mentioned in Part II.A above, commentators argue that the duty to the tax system levels the playing field between two unequally matched adversaries. Upon careful analysis, I observed that it might be more accurate to say that, when the tax lawyer enters gray areas of tax characterization, she is asked to privilege her duty to the tax system over her duty of zealous advocacy in an attempt to right the relationship between the taxpayer and the Service. From this perspective, the conventional conceptualization of the duty to the tax system requires the tax lawyer, who happens to be representing the relatively more powerful party (that is, the taxpayer), to take account of the interests of the less powerful party (that is, the federal government) whenever she exercises discretion in settling on the appropriate tax characterization of a transaction. For lesbian and gay taxpayers, however, this power differential is reversed: the more powerful party is the federal government, and the less powerful party is the taxpayer. My reconstruction of the duty to the tax system, which, on its face, may seem somewhat radical, really does no more than take account of this reversal of the power differential. It simply re-works the duty to the tax system to right the relationship between lesbian and gay taxpayers and the Service.

In this regard, my analysis here is in keeping with an "insight shared among many contemporary legal ethics scholars"; namely, "that ethics analysis must be context-specific in some respects." 168 More particularly, my analysis has much in common with recent work by Susan Carle in which she argues that where there are "obvious and substantial power imbalances among the interests affected by the representation," then the attorney should take the imbalance of power into account when making ethical judgments. ${ }^{169}$ Carle maintains that an attorney's zealousness in representing her client should vary inversely with the client's power; in other words, where the parties are not evenly matched, a lawyer should decrease her zealous advocacy as her client's relative power increases and, conversely, a lawyer should increase her zealous advocacy as her client's relative power decreases. ${ }^{170}$ This contextual approach

\footnotetext{
${ }^{168}$ Carle, supra note 40, at 117 ; see, e.g., Wilkins, supra note 19 (arguing that the methods for most effectively regulating lawyers depend on the context of the representation); David B. Wilkins, How Should We Determine Who Should Regulate Lawyers?-Managing Conflict and Context in Professional Regulation, 65 Fordham L. Rev. 465, 482-91 (1996) (discussing this topic further in the course of responding to critiques of Wilkins, supra note 19); see also Carle, supra note 40, at $117 \mathrm{n} .8$ (containing a list of articles espousing this view).

${ }^{169}$ Carle, supra note 40 , at 118 .

${ }^{170} I d$. at 119 .
} 
focusing on the relative power of the interests at stake in a representation nicely explains how a tax attorney can, at the same time, temper the zealousness of her advocacy in the representation of heterosexual taxpayers (because the balance of power generally favors them) but refuse to temper that same zealousness in her representation of lesbian and gay clients (because the balance of power is decidedly tipped against them).

\section{Concluding Remarks}

I began this Article with a discussion of the tension created by a tax lawyer's divided loyalties - that constant pull between her client-regarding duty of zealous advocacy and her public-regarding duty to the tax system. I ended the Article with the proffer of a harmonious view of these loyalties - an alignment of the duty of zealous advocacy with the duty to the tax system that is designed to preserve the interests and restore the integrity of both the individual lesbian and gay taxpayer and the tax system itself. In between, I hope to have raised your awareness of how lesbians and gay men can (and do) experience the tax system in fundamentally different - and far more oppressive-ways than heterosexuals do. More importantly, however, for those who represent lesbian and gay taxpayers, I hope to have opened an ethical space in which they can feel comfortable that protecting the interests of their lesbian and gay clients will likewise safeguard the integrity of the tax system by preventing it from being misused to further odious ends. 